
H A R V A R
B U S I N E S
S C H O O L

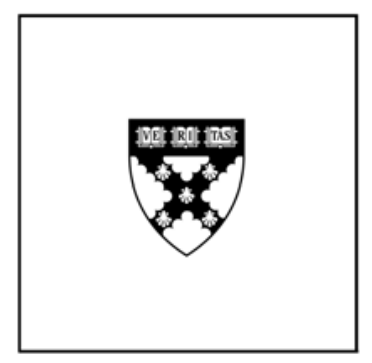

\title{
Entrepreneurship in the Natural Food and Beauty Categories before 2000: Global Visions and Local Expressions
}

Geoffrey Jones

\section{Working Paper}

13-024

August 28, 2012 


\title{
Entrepreneurship in the Natural Food and Beauty Categories before 2000: Global Visions and Local Expressions
}

\author{
Geoffrey Jones \\ Harvard Business School
}

August 2012

\begin{abstract}
This working paper examines the creation of the global natural food and beauty categories before 2000. This is shown to have been a lengthy process of new category creation involving the exercise of entrepreneurial imagination. Pioneering entrepreneurs faced little consumer demand for natural products, and little consumer knowledge of what they entailed. The creation of new categories involved three overlapping waves of entrepreneurship. The first involved making the ideological case for natural products. This often entailed investment in education and publishing activities. Second, entrepreneurs engaged in the creation of industry associations which could advocate, as well as give the nascent industry credibility and create standards. Finally, entrepreneurs established retail stores, supply and distribution networks, and created brands. Entrepreneurial cognition and motivation frequently lay in individual, and very local, experiences, but many of the key pioneers were also highly globalized in their world views, with strong perception of how small, local efforts related to much bigger and global pictures. A significant sub-set of the influential historical figures were articulate in expressing strong religious convictions. The paper concludes that by the 1990s it was evident that the success of entrepreneurial pioneers in building the market for green products created a new set of issues, especially related to the legitimacy of their businesses and of the concept of greenness.
\end{abstract}


Entrepreneurship in the Natural Food and Beauty Categories before 2000: Global Visions and Local Expressions ${ }^{1}$

\section{Introduction}

This working paper looks at the historical origins of the natural food and beauty industries before 2000. It forms part of a larger research project which examines the history of

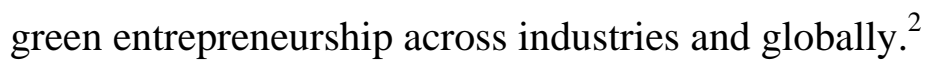

A recent estimate of the size of the global "purely natural and organic beauty products" market is $\$ 6.9$ billion. The worldwide organic food and drinks market is estimated to be $\$ 57$ billion. ${ }^{3}$ These markets represent a number of curious features, including huge variations in the relative importance of the sector even between countries which are geographically and culturally proximate. In Scandinavia, for example, Denmark has the highest per capita consumption of organic food in the world, accounting for 7.2 per cent of total food consumed. In contrast, a mere 1.3 per cent of food market in Norway, Denmark's northern neighbor, is organic. Among the other Scandinavian countries, organic food represents 4 per cent of the Swedish food market, but only 1 per cent of the Finnish. ${ }^{4}$ In other words, the cluster of medium-sized Scandinavian countries features the highest and some of the lowest rates of consumption of organic food in the world.

This study examines how these categories emerged globally. It shows that the natural food and beauty categories were primarily created by entrepreneurs on the margins of their industries, and often of their societies. There was often little initial demand for their products. As result, entrepreneurs needed to create a market. This involved investing in building business ecosystems which facilitated explaining to consumers the benefits of their products, and it involved 
co-coordinating a whole value-chain from crop production to retail distribution. This involved the expenditure of much effort and money with limited prospects of immediate financial returns. While theorists from Schumpeter onwards have acknowledge that entrepreneurial motivation can rarely be explained in terms of short-term profit maximization, the scale of the challenges faced by many of these pioneers raises questions about the "opportunities" that they identified, as well as the motivations that drove them to pursue them.

This paper contributes to an embryonic literature on "green entrepreneurs" or “ecopreneurs.” enables the identification of significant changes over time. The paper begins with a broad survey of the emergence of environmental concerns, and their institutionalization, from the nineteenth century. This provides the context for the subsequent sections on entrepreneurial endeavors in natural foods, organic agriculture and beauty. The focus in this paper is growing, making and selling products rather than the greening of logistics and supply chains. The entrepreneurs examined here are selected as influential rather than representative in any formal sense, but they do provide a wide cross-section of actors across time and geographies. A final section offers some preliminary conclusions

\section{The Emergence of Environmental Consciousness}

It is often said that nothing is ever truly new in history. Certainly contemporary concerns about the environment are not new. They can be traced directly to a variety of nature, health, and spiritually oriented movements which emerged from the nineteenth century as the consequences of industrialization became apparent, and the inspiration behind these movements had a much older philosophical and religious origins. During the nineteenth century New England transcendentalism, Hindu and Zen Buddhist religious traditions, romantic artists and literary 
figures such as William Morris and William Wordsworth, and many others, interacted with one another and served as influences on an emergent environmental consciousness. ${ }^{6}$

In the United States, the first conservation sentiments were already being expressed by the middle of the nineteenth century. In 1847 George Perkins Marsh, a U.S. Congressman from Vermont, gave a speech to the Agricultural Society of Rutland County, Vermont, focused on the destructive impact of human activity on the land, especially through deforestation, and advocating a conservationist approach to the management of forested lands. In 1851 Henry David Thoreau delivered an address to the Concord, Massachusetts, Lyceum declaring that "in Wildness is the preservation of the World." Nine years later another address to the Middlesex (Massachusetts) Agricultural Society, entitled "The Succession of Forest Trees," analyzed aspects of what later came to be known as forest ecology, and urged farmers to plant trees in natural patterns of succession. As explorers and settlers moved West, strong conservation sentiments led to the creation of Yellowstone National Park, the world's first national park, in 1872. In 1891, Congress passed the Forest Reserve Act, which allowed the President of the United States to set aside forest lands on public domain. In 1892 the Sierra Club one of the oldest grassroots environmental organization in the United States was founded in San Francisco, California, by John Muir assisted by professors from the University of California at Berkeley and Stanford University. ${ }^{7}$

It was, then, politicians, professors, and literary figures who raised concerns about protecting America's environment and natural beauty. Insofar as entrepreneurs were actors in the story, they were (and are) portrayed as despoilers rather than saviors. Yet this was never entirely true. By the late nineteenth century industrial pollution in major US cities such as Chicago and 
St. Louis was so evident that it had encouraged a handful of business leaders to organize to persuade the business community to voluntarily seek ways to control such pollution. ${ }^{8}$

The three decades after 1880 also saw the emergence of a strong environmentalist movement in western Europe, as citizens formed voluntary groups to protect wildlife and conserve nature in societies undergoing fast industrialization. There was no equivalent in southern and eastern European countries, where modern industrial growth was limited. The environmentalist movement was influenced by scientific advances which documented environmental problems such as the loss of habitats and species. A German botanist called Ernest Häckel coined the term "ecology" in 1866. Scientists were especially prominent in the first conservationist movements: the first European conservation group was France’s Société Nationale de Protection de la Nature, which was formed in 1854 as an association of zoologists seeking to protect wildlife in France and its Empire. The protection of birds from hunting, and from the growing demand for feathers to be used in women's hats and other clothes, became a focus of attention. During the 1880s several bird protection societies were founded in the United States. In Britain, female activists formed a society for the protection of birds in 1889. In 1904 this society received a royal charter and became the Royal Society for the Protection of Birds. Equivalent German and Dutch societies were formed around the same time. After the Ligue pour la Protection des Oiseaux was formed in France in 1912, every northern European country had a national lobby for bird protection. Conservation societies also developed. In Britain, the National Trust, a holding company for people wanting to donate land for preservation, was formed. At the turn of the century French citizens formed the Société pour la Protection des Paysages to protect places of cultural significance and natural beauty. ${ }^{9}$ In 1915 the Ecological Society of America was formed in the United States, which eleven years later published The Naturalist's Guide to 
the Americas, a first attempt to catalog the remaining patches of wilderness left in North and Central America.

By the new century conservation efforts had gone global. In 1907 President Roosevelt, a very active conservationist, used his Presidential address to assert that "the conservation of our natural resources and their proper use constitute the fundamental problem which underlies almost every other problem of our National life." In 1908 he convened the North American Conservation Conference, held in Washington DC and attended by representatives of Canada, Newfoundland, Mexico, and the United States. In 1913 Paul Sarasin, a Swiss zoologist, brought representatives of 16 European countries and the United States together to establish a Commission for the International Protection of Nature. However the outbreak of World War 1 disrupted it and halted plans for international congresses. ${ }^{10}$

Concerns about agriculture also contributed to an emerging environmental consciousness. As urban populations demanded increasing amounts of food, there was alarm that the fertility of soil was declining. There was a worldwide search for natural fertilizers, which focused first on exploiting deposits of guano on the west coast of South America, and then nitrates from the same region. The research of Justus von Liebig, a German chemist who identified the role of nutrients in plant growth, intensified concerns about soil fertility. By the middle of the century Karl Marx was blaming declining soil fertility on the exploitative character of capitalist agriculture, and making the case for agricultural sustainability. ${ }^{11}$ The more immediate response, however, was the use of chemical fertilizers to raise productivity. During the interwar years, by which time the chemical fertilizer industry had been given a boost by wartime import restrictions on natural nitrates, the early proponents of organic farming such as Rudolf Steiner responded to the introduction of mechanized and industrialized agriculture. (see Section 3.2) 
The era of world wars, virulent nationalism, and the economic crisis during the 1930s, did not provide an especially favorable context for the growth of environmental consciousness. The membership of most of the conservationist groups founded earlier stabilized. There were few new societies except the Council for the Protection of Rural England, established in $1926 .{ }^{12}$ It was often associated with right-wing political extremism. During the Nazi era in Germany after 1933, elements of the Nazi Party became attracted to organic farming, while Hitler and some of his key lieutenants were vegetarians, though claims that the Nazi regime was protoGreen are off the mark. Whatever the personal views of certain individuals, the regime prioritized food supplies and the use of chemical fertilizers to get them, quite alone engaging in warfare and the perverse use of science. ${ }^{13}$

After the end of World War 2 in 1945, the destructive impact of the war and the need for reconstruction provided the background for the re-emergence of environmental concerns. In 1946 a small group of American scientists formed the Ecological Union, resolving to take direct action to save threatened natural areas. In 1950 the name was changed to The Nature Conservancy. In Western Europe conservation movements were also renewed, even if European governments and most of their populations were pre-occupied with reconstruction and the application of chemistry to agriculture to better feed their populations. Environmental concerns spread beyond northern Europe. In 1955 activists formed Italia Nostra to preserve Italy’s cultural heritage and rural areas. International links began to be restored; in 1946 the Swiss League for the Protection of Nature sponsored a conference that assembled some of the leading conservationists in Europe. Under the auspices of the newly created UNESCO, the International Union for the Conservation of Nature (IUCN) was formed in 1948 as an international association of government conservation offices and nongovernmental conservation organizations. 
The perceived exclusive focus of IUCN on governments led to the creation of the World Wildlife Fund following the Morges Manifesto, which was signed in 1961 by 16 of the world's leading conservationists, including biologist and African wildlife enthusiast Sir Julian Huxley, the IUCN vice president, Sir Peter Scott and the director-general of the British Nature Conservancy E. M. Nicholson. The Morges Manifesto stated that while the expertise to protect the world environment existed, the financial support to achieve this protection did not, and established the World Wildlife Fund as an international fundraising organization to work in collaboration with existing conservation groups. In 1961 the first national organization opened in Britain. An American organization followed in the same year. National branches opened throughout Europe during the 1960s. ${ }^{14}$

Alongside the renewal of the conservation movement, a number of accident and pollution incidents worked to expand environmental concerns. During the 1950s a number of incidents heightened awareness of the dangers of pollution. In Britain, vicious smog in London was estimated to have killed 4,000 people in 1952. In the following year at least 200 people died as a result of smog in New York City. In Japan, "Minamata disease” was first diagnosed in Minamata city in Kumamoto prefecture in 1956. It was caused by the release of methyl mercury in the industrial wastewater from a chemical factory. The highly toxic chemical accumulated in shellfish and fish in Minamata Bay and the Shiranui Sea, which when eaten resulted in mercury poisoning. ${ }^{15}$

The environmental impact of the chemicals used in recently invented synthetic detergents became apparent around the same time. While the dirty water from household washing was diverted into treatment plants before being released, certain widely used and functionally important detergent ingredients did not readily biodegrade as the water was treated. These 
chemicals started to accumulate within the treatment plants, and soon found their way into rivers, lakes, and streams. Detergent foam began to be seen in Europe and the United States. By the early 1950s, synthetic detergents had been identified as the cause of the foam when tests of water and sediments showed high levels of non-degraded surfactants, a primary cleaning agent in synthetic laundry powders. By the late 1950s, the highly visible detergent foam was found in rivers and lakes in Europe and North America. ${ }^{16}$

The emergence of the consumer movement on both sides of the Atlantic began to articulate rising concerns about safety in many industries, as a perception emerged that many manufactured products were harmful. The threats posed by the emulsifying agents used in foods raised concerns. In one incident in 1960, a leading brand of margarine appeared to have given much of the Dutch population an unpleasant skin rash. ${ }^{17}$ A series of catastrophic incidents highlighted the risks to personal health of certain products, and re-inforced the growing skepticism concerning the safety of the science which lay behind industrial products. In Europe, the drug Thalidomide, marketed between 1957 and 1961 as a remedy for morning sickness during pregnancy, turned out to produce horrific birth defects. In France, a talcum powder marketed in 1972 as talc Morhange killed 36 children and injured a further $240{ }^{18}$

The evidence of such environmental disasters was accompanied by the appearance of books which were influential in changing opinions on the environment. These books essentially reformulated many of the ideas put forward decades earlier by pioneers of organic farming such as Rudolf Steiner and Eve Balfour which had struggled to achieve a voice during the decades of economic depression, war, and postwar reconstruction. ${ }^{19}$ Among the earliest and most influential of such books was Rachel Carson’s Silent Spring (1962). Carson, a former biologist at the U.S. Fish and Wildlife Service, had an enormous impact in raising both US and European awareness 
to the detrimental environmental impact of widely used and produced pesticides like DDT. ${ }^{20}$ The book provoked other European and American studies, including Jean Dorst and Paul Ehrlich, which both reached further audiences, and extended environmental concerns to issues such as over-population. ${ }^{21}$ Carson also exercised an important influence on a new generation of entrepreneurs who were interested in starting business ventures focused on countering the harmful effects of chemicals, and building new businesses which would help the environment, rather than damage it.

At least as important as Carson was the impact of the US space program resulted in a new awareness of Earth as a planet. In 1968 the crew of Apollo 8 took the first photograph of Earth from space. Named "Earthrise," the photograph was widely adopted by the environmental movement. ${ }^{22}$ Images of the earth from space became pervasive, and they marked a major cognitive shift in how people perceived the "environment.” In 1989 Time magazine designated “Endangered Earth” as "Planet of the Year”, in place of its usual man or woman of the year. ${ }^{23}$

The growth of environmental awareness was surprising even for people who had campaigned on environmental issues. One prominent member of the Sierra Club later remarked;

"During the sixties there were many things that contributed to rapid change in attitudes. All of a sudden, in the space of a very few years, an almost universal concern for the environment emerged. Those of us who had been active in the conservation movement for many years, and formerly regarded as eccentrics, all of a sudden found ourselves respectable, and no longer called conservationists, but "environmentalists.” The change came about with remarkable suddenness. It was not a change that we had anticipated that soon nor that quickly. We had foreseen a gradual evolution in prevailing attitudes on conservation--and environment--in this country. The public's concern with environmental questions that now prevails, we had projected 
to evolve gradually during the next few decades. But then, I guess the cultural revolution was an event we could not imagine, much less anticipate. It shook up everything and everybody and left, among other things, a strong environmental awareness that had a profound impact on Congress, government bureaus, and corrective legislation. Even industry reluctantly made concessions to the new environmental ethic."24

By the early 1970s discussion of the threats faced by the environment had become quite widespread. Among the most influential studies was the 1972 Club of Rome ${ }^{25}$ report The Limits to Growth. The Club of Rome had been founded four years previously by the Italian industrialist Aurelio Peccei and the British scientist Alexander King who "came together to discuss the dilemma of prevailing short-term thinking in international affairs and, in particular, the concerns regarding unlimited resource consumption in an increasingly interdependent world.” The Limits to Growth modeled the consequences of rapid population growth under conditions of limited natural resources, and predicted that by the middle of the twenty-first century the earth's ecosystem would collapse. ${ }^{26}$ In the same year Only One Earth was published. This book was rapidly created at the request of Maurice Strong, the first UN Secretary of the Environment Program (UNEP), and brought together contributions from the world's leading scientists and environmentalists. It served as the common preparatory document for the participants in the first UN Conference on the Human Environment, held in Stockholm in 1972.

The Stockholm Conference was the UN's first major conference on international environmental issues, and marked a turning point in the development of international environmental politics. It was attended by the representatives of 113 countries, 19 intergovernmental agencies, and more than 400 inter-governmental and non-governmental organizations. The meeting agreed upon a Declaration containing 26 principles concerning the 
environment and development, an Action Plan with 109 recommendations, and a Resolution. The Stockholm meeting resulted in a rush of new environmental legislation all over Europe. ${ }^{27}$ It also played a significant role in diffusing environmental consciousness beyond the Western developed countries. In Latin America, for example, the Colombian government instituted its first laws on the environment as a result of the conference. ${ }^{28}$

The most important dimension of the Stockholm Conference, however, might not have been the United Nations meeting at all. Alongside the formal event there were many parallel conferences and thousands of, mostly younger, people, who were concerned about the environment. These informal events were more radical, and more concerned to place environmental issues into a wider political, economic and social context. There was a particular focus on energy issues, but food was also an issue. There was a heated debate on the extensive use of pesticides and fertilizers to produce more and faster in order to meet the increasing demand for food. A group of Japanese who were disabled by the Minamata disease came to the events with a warning about the adverse consequences of the kind of fast growth then being seen in the Japanese "economic miracle". 29

The appearance of environmental activists at the Stockholm event reflected the institutionalization of the environmental movement. In the US, the first Earth Day in 1970 represented the culmination of growing public concern over a series of well-publicized environmental disasters in the late 1960s. ${ }^{30}$ These included the disastrous Santa Barbara oil well blowout which spilled 200,000 gallons oil into the Californian coastline for eleven days, which directly led to the National Environmental Policy Act in $1970 .{ }^{31}$ The Friends of the Earth was founded in San Francisco in 1969 by well-known American naturalist David Brower, a member of the Sierra Club. When the Sierra Club refused to oppose the development of nuclear power in 11 
the US, Brower left it and started his own group that became central to the rise of the new environmental or ecological movement. In 1971 this group went international after a meeting of environmentalists from Sweden, France, the UK and the US in Sweden. ${ }^{32}$

Devastating nuclear accidents at Three Mile Island in Pennsylvania in 1979 and Chernobyl in the Ukraine in 1986 contributed to growing public alarm concerning the environmental damage being inflicted on the planet, as did the 1989 American oil tanker Exxon Valdez oil spill in Prince William Sound, Alaska. In 1983, the United Nations created The World Commission on Environment and Development (WCED), also known as The Brundtland Commission after the name of its Chair Gro Harlem Brundtland, who was soon to become the President of Norway. ${ }^{33}$ In 1987, WCED published the report Our Common Future, in which the commission concluded that efforts at environmental protection and sustainability were strongly outpaced by advancing harm and deterioration. The Brundlandt Commission provided a definition of the concept of sustainability. "Sustainable development”, the report noted, “is development that meets the needs of the present without compromising the ability of future generations to meet their own needs.” 34

By then, concerns for the environment extended beyond the small circle of radical activists of forty years previously, though there remained no consensus on the nature of the problems, their severity, and their solution.

\subsection{Emergence of Natural Food Businesses before World War 2}

The origins of today's natural foods business can be found in social movements which started during the second half of the nineteenth century. Among the first manifestations of this trend was the health reform movement which emerged in the United States and Europe. In the 12 
US, this was centered in Boston. It was founded by Sylvester Graham and the American Physiological Society. It emphasized "good diet, water, exercise, and fresh air" as central to health. ${ }^{35}$ The product most strongly associated with the movement was whole-wheat bread, and its proponents strictly forbade the consumption of meat, alcohol, and patent medicines.

Dr. John Harvey Kellogg, from Battle Creek, Michigan, coined the term “health foods” in 1892 and his Sanitarium Health Food Co. made the branded first line of health foods in the U.S. Kellogg, the son of members of the Seventh-Day Adventist sect, developed a business out of the health principles of the sect, including vegetarianism and taking exercise. By 1876 he was medical director of the sect's upscale health spar in Battle Creek. Concerning about the digestive qualities of bread, Kellogg asked his brother Will to experiment with a wheat paste, which was accidently left out to stand all night, and dried out. He ran the product through a set of rollers and ended up with a flaked wheat which became a breakfast cereal. The brothers set up a company to market breakfast cereals alongside a coffee substitute. When competition in breakfast materials mounted, Will took the opportunity of his stricter brother being away in Europe to add sugar to his toasted cornflakes, creating the now famous Kellogg’s Cornflakes. ${ }^{36}$

The US health reform movement was heavily influenced by developments in Britain. Late nineteenth century Britain saw a major interest in nutrition, with continuous surveys of the working class diet. ${ }^{37}$ There was also a vigorous vegetarian movement. The world's first Vegetarian Society was founded in Britain in 1847, and societies in Germany, the Netherlands and elsewhere followed. ${ }^{38}$ Early vegetarians from the US visited Britain to study methods of planning meals for good health. ${ }^{39}$ Reflecting the wider globalization of environmental concerns, the International Vegetarian Union, a union of national societies, was founded in $1908 .{ }^{40}$ 
Health food products were initially sold spas and sanatoriums, like those founded by Dr. Kellogg. Before 1914 they were also being sold both in the United States and Britain in a new retail channel - the health food store. In Britain, the first health store originated in 1898 in the town of Birmingham when a group of vegetarian businessmen established a vegetarian restaurant, store and hotel. It was managed by John Henry Cook, a vegetarian and temperance advocate, who coined the term "health food store" after a customer asked him what foods she should be eating for health. Cook took over the store when the rest of the business was sold in 1901. The business took the name of Pitman Health Food Stores after the prominent publisher, inventor of shorthand and vegetarian Sir Isaac Pitman, who had recently died. Cook stocked his store with fresh fruits and vegetables, and packaged breakfast foods imported from Kellogg's factory at Battle Creek. By 1908, by which time Cook had three stores, he established a factory making health foods. The retail business was sold, and Cook became a supplier to the burgeoning health store sector. By 1925 his catalogue was being mailed to 500 health food stores. Six years later Cook wrote a 181 page book entitled "How to run a Health Food Store Successfully by the founder of the first." ${ }^{41}$

Both in Britain and the United States the number of health food stores expanded in the interwar years, most of which were small, and family-owned and run. In the United States, the better known stores, which also set up business as distributors, included Sherman Foods, founded in 1924 in New York, Kahan \& Lessin, founded in 1932 in Los Angeles, and Landstrom Co., founded in San Francisco in $1931 .^{42}$ Subsequent leaders of the movement included Anthony Berhalter, a Chicago baker, who organized a group of manufacturers and retailers to form the American Health Food Association in 1937. ${ }^{43}$ In Britain, however, the Cook business was wrecked during World War 2, when his daughter's own health food shop was destroyed by 
bombing, while the large factory he had built in 1929 was requisitioned by the government for munitions manufacture. ${ }^{44}$

A second, related movement took shape as health reform yielded to a new generation of food reformers. In Europe, there was a particularly strong interest in natural foods in Germany, which also influenced developments in the United States. While one strand of this influence tended toward an association between natural food, the outdoors, exercise, health, and even fascism, much of the activity that came out of Germany advocated a more romantic, nature worshipping lifestyle. ${ }^{45}$

The Life Reform (Lebensreform) and Reform House (Reformhaus) movements were at the heart of developments in Germany in the early twentieth century. ${ }^{46}$ The Life Reform movement became the official name of a network of participating groups, many of them devoted to vegetarianism and natural healing. These groups were influenced by, and in turn influenced, the so-called physical fitness and health culture (Körperkultur) of the Weimar period, as well as the hygiene movement and its hygiene associations that arose in the 1920s. Other closely related groups, whose members were often active in Life Reform included the "nature cure" spa entrepreneurs, nudist communities, and hiking associations.

The 1920s saw the rise of the so-called reform house movement, and the communities and trade organizations which manufactured "Reform products" (Reformwarenhersteller), which became the center of the movement. Reform houses were specialty retail shops which sold products that qualified as "life reform" products. Their owners were members of the Life Reform movement, and provided advice and information about both the movement and its products to customers. Through the channel of the reform houses, these small businesses marketed products aimed at letting people live a healthier life. The most important product groups were nutritional, 
curative, and health food products, as well as personal care and cosmetics products. The industry founded periodicals for its customers in which the teaching and principles of Life Reform were disseminated to the public. ${ }^{47}$ Although Germany was the main center of activity, there were some parallels elsewhere in Europe. In France a small dietary movement emerged when few consumers who were questioning the quality of their diet, and starting in the early 1920's, dietary products shops opened in the country. ${ }^{48}$

Individuals were important in diffusing concepts across national borders. Benedict Lust, born in 1872 and raised in the Black Forest, Germany, was instrumental in transferring many such German concepts of natural food and healing to the United States. He first travelled to the United States in 1891, to work as a professional waiter in New York City, but contracted tuberculosis and returned to Germany for the water "nature cure treatment" from the naturopath Father Sebastian Kneipp. When he recovered, he made Father Kneipp’s teachings about natural medicine his own as well, and immigrated to the US in 1896 as Kneipp's American representative. To become established in the US, he enrolled and graduated from the New York Homeopathic Medical College in $1901 .^{49}$ In that year, he founded the American School of Naturopathy in New York City, the first naturopathic medical school in the world. He also founded the Naturopathic Society of America, renamed the American Naturopathic Association in 1919, the first national professional organization of naturopathic physicians in the US. ${ }^{50}$

With the financial help of his wife, a skilled health food cook and advocate of a nut and fruit diet, and brother-in-law, Lust founded his own spa sanatorium, Yungborn, in New Jersey. ${ }^{51}$ In 1913, he founded a second Yungborn spa in Florida. Lust introduced to the United States the major naturist movements in Europe, including hydro-therapy, herbal remedies, air and light baths, and vegetarian diets, and translated a number of the natural health classics written by 
Germans. ${ }^{52}$ Lust's magazines also introduced the United States to the Indian concepts of Ayurveda and Yoga. The Indian healer Paramahansa Yogananda was one of several Indians who wrote articles for his journal Nature's Path in the 1920's. ${ }^{53}$ Lust was harassed both by the authorities and medical associations for his unconventional approach to healing, as it involved massage and nude sun bathing at his health resorts. ${ }^{54}$

A related interest in "physical culture" grew in the late nineteenth century America. Bernard McFadden, born in Missouri in 1868, was an important figure. After his mother died of TB when he was four, and he appeared to develop it when he was 12, he saw a gym, but could not afford the membership, so established his own gym with bars and dumbbells. He seemed to recover, got a job in a coal mine, and got the idea that his mission was to teach the "gospel of health.” Moving to New York, in 1899 he founded a magazine called Physical Culture, and published the five-volume, 2,969-page Encyclopedia of Physical Culture (first issued in 1911 and periodically revised), and numerous other books and pamphlets. He opened a chain of onecent Physical Culture restaurants, and established spas which he called "healthatoriums."

Even amongst the pioneers of natural foods and lifestyles, McFadden was an eccentric. Following his theory of voice development, he would periodically, and without warning, break into loud mooing or braying. He kept the same clothes for decades, wearing them until they were literally in tatters. But if Macfadden was sometimes absurd, he was far from ineffectual as an entrepreneur. Physical Culture grew from five thousand readers to one hundred thousand in the first two years, and up to half a million by 1918. As the magazine prospered, it became more general, running articles on how to skate and how celebrities kept in shape. In 1935 the combined circulation of his magazines was over 7 million. ${ }^{55}$ 
MacFadden was an early influence on one of the American pioneers of supplements and vitamins, Dr. Forest Shaklee. Born in Iowa, he had tuberculosis at birth, and spent his childhood in convalescence at a farm, gathering plants and herbs. He read Physical Culture, and adopted his diet which included avoiding refined white flour, sugar and too much salt, although at some stage he concluded that MacFadden had a "streak of chicanery". After he was diagnosed with an appendicitis, he went to see a chiropractor, who figured it was a displaced vertebra. Shaklee graduated as a chiropodist in 1915, and took over a practice. He became interested in vitamins, corresponding with Casimir Funk, a Polish biochemist, who had first discovered them. He opened a sanitorium, and kept patients on a vitamin-rich diet. Diagnosed with cancer in 1921, he refused amputation, sold his clinic, and went to live on a healthy diet of fresh food and vitamins. He recovered, and in 1924 opened the Shaklee Clinic in Iowa. In 1929 he was ordained as a Christian minister. During the 1930s he developed a business selling nutritional foods from his clinic, but in 1941 his wife died, and he retired two years later - it turned out temporarily. ${ }^{56}$

It was striking that none of these pioneers of the natural food business came from established foods firms which were, and to remain for a long time, wholly skeptical. The only exceptions were very niche products, such as vitamins and food supplements, where conventional manufacturers and retailers became involved. In interwar Britain, for example, consumer products companies, including patent medicine companies, made supplements and vitamins. Glaxo sold Ostelin, the first vitamin concentrate sold commercially in Britain, in 1924. It and other patent medicine and pharmaceutical companies such as Allen \& Hanbury and Burroughs Wellcome sold a variety of supplements during the 1930s. Even the chocolate company Cadbury entered the health foods market with a diabetic chocolate in $1938 .{ }^{57}$ 


\subsection{Organic Agriculture}

From the early twentieth century proponents of what would now be called "organic farming” responded to the introduction of industrialized agriculture and the growing application of chemical fertilizers. It was in Germany where such farming first spread on a significant scale. Although the Life Reform movement was primarily urban, some members began to work as farmers or gardeners. They pursued ideas of natural agriculture which included careful composting, green manuring, and mulching. The Life Reformers were also vegetarians and believed in farming without the use of animals. In 1927/28, the first 'organic' organization the Community of Natural Farming and Settlement (Arbeitsgemeinschaft Natürlicher Landbau und Siedlung) was founded in Germany. It focused on fruit and vegetable production without artificial fertilizers and pesticides. ${ }^{58}$ There was some international diffusion of these ideas. A wave of alternative groups in California experimented with organic farming emerged, starting with the so-called "Nature Boys" in the 1920s. They were either German immigrants or Americans influenced by the Life Reform movement, and were concentrated in Southern California and Florida, where they are sometimes considered to be the origin of the hippie movement.

Germany was also the most important home of the biodynamic agriculture developed by the Austrian Rudolf Steiner. Steiner originally studied science and philosophy in nineteenth century Vienna, but upon moving to Berlin in 1897 became involved with "Theosophy", an occult movement heavily influenced by Asian religions. Steiner disagreed with the movements leaders, however, maintaining the importance of scientific investigation and asserting the unique importance of Jesus Christ. In 1913 broke away to found his own school of Anthroposophy. In his research, Steiner explored the forces active in living organisms. His agricultural theory 
emphasized the relationship between the earth and the heavens. He believed that planetary rythms affected the quality of plants, and that farming needed to be conducted in accordance with astrological and lunar movements. There were also distinct farming practices. He saw mixed farming as the only viable form of agriculture, with the soil, plants, animals, woodland and birds on each farm in the correct proportions. He also emphasized the importance of the Rule of Return, arguing that artificial fertilizers were unnecessary if the land was properly cared for. In 1924 Steiner gave his Agriculture Lectures to an audience of anthroposophic farmers in Poland. Within a year he was dead, but the influence of his ideas was not. Steiner's ideas were applied especially to large estates in the eastern parts of Germany. ${ }^{59}$ The trademark Demeter was introduced in 1928 as a way to distinguish biodynamic products from others. However the influence of Steiner's ideas was much wider than Germany. ${ }^{60}$

Steiner did not use the word organic, but in time some of his followers did. In Britain, Steiner's work was read by Lord Northbourne, who studied and later taught agriculture at the University of Oxford. Northbourne's book Look to the Land, published in 1940, contained probably the first use of the term "organic farming." In the book, Northbourne asserted that "the farm itself must have a biological completeness; it must be a living entity, it must be a unit which has within itself a balanced organic life." ${ }^{61}$ Meanwhile Steiner’s ideas reached the United States through American students who studied with him. In 1926 members of New York City's Threefold Group bought a farm in rural Rockland County, about 30 miles northwest of New York City, and began to introduce his ideas. In 1933 they held their first summer school, and one of the invited speakers was Ehrenfried Pfeiffer, a German chemist who came under the influence of Steiner. During the early 1930s he converted a farm owned by the wealthy daughter of a former prime minister at Loverendale in Walcheren in the Netherlands to the principals of 20 
biodynamic farming. He became a regular speaker at the Threefold summer school, and settled permanently in the United States in 1938, where he created a model biodynamic farm and training center at Kimberton in Pennsylvania. ${ }^{62}$

In Europe, the biodynamic movement struggled during the 1930s. In Germany, it had some sympathizers in the Nazi regime, but ended up being banned. Some Germans moved to Loverendale, but struggled to break out of a small niche. Pfieffer emigrated to the United States. The German occupation of the country in 1940 began an era of strict agricultural regulation in which the opportunities for organic farming were close to zero. ${ }^{63}$

In the United States and, especially, Britain, agricultural systems in non-Western countries served as powerful influences for organic farming. ${ }^{64}$ In 1907, Franklin H. King, a agricultural professor, resigned from the U.S. Department of Agriculture, and traveled throughout China, Korea and Japan to observe the agricultural methods of the local population. Alarmed by the use of chemical fertilizers and pesticides in America, King reported that Asian peasants had been able to maintain fertile soil for thousands of years by using natural manure compost and rotating crops regularly. In a 1911 book, he called for a "world movement" for an alternative agriculture based on the principles he had seen in Asia. ${ }^{65}$

In Britain, and subsequently elsewhere in the English-speaking world, two British scientists working in colonial India exercised major influences on the emergence of organic agriculture. The son of a farmer, Sir Albert Howard was trained in agricultural chemistry at the Royal College of Science, and went on to Cambridge University, where he studied natural sciences. He joined the British colonial service, and in 1905 he was sent to India, where he 
remained until 1930. He learnt about the traditional, chemical-free agricultural methods still practiced in India and conducted his own experiments. ${ }^{66}$ As evidence for the success of his method mounted, he began to argue against the use of chemical fertilizers and for the environmentally informed ecological farming practices. In his book, An Agricultural Testament, he warned that:

"The slow poisoning of the life of the soil by artificial manures [chemical fertilizers] is one of the greatest calamities which has befallen agriculture and mankind... The flooding of the English market with cheap food, grown anywhere and anyhow, forced the farmers of this country to throw to the winds the old and well-tried principles of mixed farming... The spraying machine was called in to protect the plant; vaccines and serums the animal; in the last resort the afflicted livestock are slaughtered and burnt. This policy is failing before our eyes.”’67

There were some obvious similarities between Howard and Steiner, although Howard was skeptical about biodynamic cultivation, and had no interest in his esoteric and cosmic theories. In contrast to Steiner's philosophical basis, Howard's approach was inductive - he looked at practice, and then sought to develop a theory which reflected the evidence. ${ }^{68}$

Also in colonial India, Robert McCarrison, a British doctor, undertook research in Coonoor on the relationships among soil fertility, food quality and human nutrition. Studying the Hunza tribesmen, he discovered that their healthy lives rested on a nearly vegetarian diet of whole grains, vegetables fruit and milk products. He also identified a decrease in food quality caused by the increased use of mineral nitrogen fertilizers. ${ }^{69}$

Howard and McCarrison laid the foundation for a continuing dialogue on the merits of organic agriculture in Britain, and other English-speaking countries, after the end of World War 
2. One of the most influential British figures during the 1940s and 1950s, Lady Eve Balfour, was influenced by Sir Howard's and McCarrison's work. Aged 17, she enrolled at Reading University in Britain to study agriculture. She wanted to run her own farm, and in 1919 she and her sister acquired and moved into New Bells Farm in Suffolk. In 1938 she read The Wheel of Health and Famine in England, and learned about Sir Robert McCarrison and Sir Albert Howard. Both had worked in India, and stressed that the core of health rested in good quality food, based on healthy and fertile soil. She began using compost on her farm. In 1939, she launched the Haughley Experiment on farmland in England in 1939 as the first scientific comparison of organic and conventional farming. Her 1943 book The Living Soil presented the initial findings of the Experiment, and influenced a wide group of people who went on to form the organic advocacy group known as the Soil Association in 1946.

Balfour's book brought together several strands of thought on farming and nutrition, and although it contained little that was fundamentally original, it was successful at making the case for organic farming accessible. There were five editions of The Living Soil by 1945 and eleven editions before the final one in 1976 . The book made the case that the soil is biologically active, and that the role of micro-organisms in keeping the soil fertile was important. The key to keeping soil fertile was held to be the return of organic material in the form of compost. Balfour argued that the healthiest food was fresh and had little preparation. Balfour maintained that all living things were integrated in a holistic way and mutually dependent. The book was deeply global in its approach, drawing on evidence on farming and diet throughout the world. The original book postscript, written during the middle of the War, also strongly emphasized the religious motivation behind Balfour's work: 
"The false gods of comfort and money, must be dethroned, and the Christian God of service put in their place. Service to God, service to our soil, service to each other, and, through each other, to the community and the world" 70

The Soil Association had a number of interesting features. The founders, like Balfour herself, were affluent upper class figures. Although there were farmers among them, they were not dominant. It was highly focused on research and education. In 1947 it launched a journal, Mother Earth. Balfour also concerned from the beginning to engage with consumers. This involved educating them. The Association focused first on selling reprints of articles on organic farming and nutrition, but then in 1960 opened a shop in London called Wholefood to sell the produce of its members. By the end of that decade it had also begun work on the development of the first set of farm standards in Britain. ${ }^{71}$

In postwar Germany, the organic tradition continued, with stronger roots among traditional farmers than in the English-speaking countries. In Switzerland, too, organic farming was quite influential. Hans Müller developed during the 1950s and 1960s a method known as "organobiologic agriculture" in the gardens of the School of Agriculture in the Swiss city of Möschberg, which was based on composting and tilling the surface. Heavily influenced by Christian values, Müller and his wife grew organic food and sold it through the post, to the Swiss co-operative retail chain Migros, and to shops belonging to the Reform movement. They were joined by a German doctor called Hans Peter Rusch. He developed a soil fertility test method called "Test Rusch" which was sold to farmers. These ideas had a particularly influential impact on the emergence of organic farming especially in Switzerland and Germany, although by the 1970s the "Test Rusch" had been abandoned as it rested on false scientific foundations. ${ }^{72}$ 
The interest of some Swiss and German farmers in the organic movement was atypical in Europe. At the other extreme was the Netherlands, where government policy focused on raising production and productivity through large land reclamation and the vigorous use of chemical fertilizers. During the postwar decades, the Netherlands featured the highest use of pesticides and ferti lizers per hectare in the world. A Dutch branch of the Soil Association was founded in 1950, but it remained a marginal force. During the late 1960s student activists founded small temporary shops to sell alternative products, and in 1973 a journalist and others founded De Kleine Aarde, a center to support experiments in organic agriculture. This established ten or so centers to buy and sell organic products of farmers, but by the mid-1980s most had gone bankrupt. There remained little interest among Dutch farmers or consumers in organic foods until the 1990s, when EU policies mandated governments to provide more support for organic products. ${ }^{73}$

In France, health concerns were the initial drivers of the organic movement. An influential figure was Henri Charles Geffroy, who in 1946 created La Vie Claire, a magazine designed to disseminate information on natural products. Born in 1895, he had suffered from poor health, and was treated by doctors highly influenced by the work of Pasteur in which all kind of raw vegetables were banned. He was gassed during World War 1, and continued to suffer from the consequences. By 1935 doctors gave him only three months to live. Fortunately, he came across an article about a treatment based on Reform House practices in Berlin that saved people affected by tuberculosis or were gassed during the war. Patients were advised to avoid processed products, meat and animal by-products, and they were prescribed a diet based exclusively on vegetables and cereals, fruits and vegetables were usually eaten raw. Henri- 
Charles adopted this lifestyle and regained his strength. He then decided to devote himself to teaching others about his new healthy lifestyle.

The new magazine generated other businesses. In March 1948, a cooperative is created with a group of friends to offer services to subscribers of La Vie Claire. The cooperative sold fruits and vegetables grown without chemical fertilizers, wheat bread and useful items to grow small crops. In 1950 he developed a new recipe for pure wheat bread. In the following year he launched a company, L'Aliment Saint, which sold his bread along with other organically grown products. The company was later renamed La Vie Claire, and publicized a diet inspired by the German Reform House movement with a strong emphasis on organic agriculture. ${ }^{74}$

A number of French doctors after World War II had expressed concerns about the effects of fertilizers and pesticides, and these voices were influential in driving the organic movement. In 1952 the Association Française pour une Alimentation Normale was founded by a group of doctor's nutritionists and homeopaths to advocate a return to a healthier diet, though it struggled to gain traction. In 1959 some of its members and supporters of the Soil Association created the Association of Organic Farmers in the West of France, but its forty members only included 4 or 5 farmers, and physicians and pharmacists dominated.

This emergent organic movement split during the early 1960s. The application of Rusch's methods led to the use a natural fertilizer from seaweed called lithothamme. In 1963 this product was commericalized by a firm called Lemaire Boucher. Farmers using this fertilizing method, needed to buy fertilizers from Lemaire Boucher, which also sold grain to its customers. The radical elements among the organic movement disliked such commercialization, and in the following year founded an organization known as Nature et Progrès. The founders of N\&P, 
André Louis, a retired agronomic engineer and Matheo Tavera, architect, were disciples of the anthroposophy movement and bio-dynamists, but they also sought a close relationship with consumers, which enhanced the organization's lobbying efforts which were focused on securing the adoption of a government-approved set of guidelines. In 1972 a meeting in Versailles attracted several thousand people, signaling the advent of a much larger organic movement in the country. ${ }^{75}$ As a later president remarked

"All of a sudden the public learned about what they were really eating, hormones fed to chickens...battery raised chickens. People were shocked, they realized, like I did, that farmers have been using all these nasty stuff to feed their animals and crops for $10 . . .20$ years for some of them. It seriously raised consciousness among people. That's when the first members of N\&P decided that we could change things; we could go back to a natural way of doing things." 76

In the United States, organic farming was driven by lifestyle choices and alternative ideologies. Walnut Acres, a Pennsylvania farm and mail order natural foods company, was founded in 1946 by Paul and Betty Keene. Keene, a math teacher at a New Jersey college, had learned about the work of Howard while living in India on a two-year teaching contract during which, in 1939, he had met the Indian independence campaigner and spiritual guru Mahatma Gandhi. As Keene later recalled "My experience in India inspired me to change my life completely. I felt the people of India possessed something I lacked in my life....For them, life was more than possession, and in their poverty lay their richness. After my contacts with Indian life I was no longer content with formal teaching. I had to get closer to the basics of life. I had to become more directly dependent on the soil.," 77 
Having met his wife, an American born to missionary parents in India, and returning to the United States, the couple began teaching at Three Fold farm, and met Ehrenfried Pfeiffer, working at the Kimberton farm he had started in Pennyslvania. In 1946 they bought a 100 acre farm and began organic farming: their first harvest came from six old apple trees on the farm. A mail order business followed selling the products of the farm. By the 1960s, as the business grew, Walnut Acres began buying natural foods produced elsewhere for its mail order business, becoming a substantial business. ${ }^{78}$

It was Jerome I. Rodale who most prominently built the identity of the American organic foods movement. He was also an unusual case of an entrepreneur who entered organics from an established conventional business. Rodale, a son of a New York grocer and one of eight children, was physically weak as a child. In 1914 the death of his father, at the early age of 50, when he was only 15, heightened his health concerns. Changing his surname from Cohen to Rodale in 1921 because of fear that anti-Semitism was retarding his career, he worked for a time as an accountant, including for the Internal Revenue Service, until 1923, when he and his brother Joe established a small electrical manufacturing business, Rodale Manufacturing, in New York. In 1930, after the business had experienced falling sales because of the Great Depression, the company moved to cheaper premises in Pennsylvania. At this stage, Rodale began to pursue his earlier interest in publishing, starting to publish magazines and books as a small and unprofitable part of the larger and profitable electrical manufacturing business. ${ }^{79}$

Rodale's pre-occupation with health were reflected in his publishing activities. In 1939 he wrote a book on Sleep and Rheumatism, which recommended people slept in bigger beds on ergonomic mattresses. ${ }^{80}$ In his new rural location, he planted his own vegetables in the small 
yard behind his house. However it was an encounter with the work of Sir Albert Howard which transformed Rodale. He bought a farm near Emmaus in Pennsylvania on which to experiment with Howard's methods of building up the soil. Although the farm was initially loss-making, after a year Rodale noticed that his health was improving as he worked on the farm and his family ate an organic diet. In 1942 he started a magazine called Organic Farming and Gardening to chronicle his experiments and progress on the farm. The first issue featured an article by Sir Albert Howard. Rodale printed 14,000 free copies of the first issue. He sent them free to farmers, but only received 12 paid subscribers in return. Both in the US and elsewhere, the conservatism of farmers were a considerable obstacle to creating viable sources of supply of organic products. There was more of market among home gardeners, and the journal was soon renamed Organic Gardening, and it began to sell in larger numbers. ${ }^{81}$ The magazine, and the many books published under the imprint Rodale Press, were major drivers of putting the term "organic" into more widespread use. ${ }^{82}$

After World War 2, Rodale intensified his efforts to promote organic agriculture. In 1947 he launched the Rodale Diet, which listed foods that people wanting to follow an organic diet could eat. In the same year he launched a nonprofit foundation (the US Soil Association, later known as the Rodale Institute) to encourage research in organic farming. It was financed by Rodale Manufacturing, which was increasingly profitable, just as Rodale Press was consistently unprofitable. The foundation supported the research of Ehrenfried Pfeiffer - it was only a twohour drive between Rodale’s farm and the Kimberton farm - on mice, which showed that mice fed on an organic diet were less irritable and less likely to die of stomach disorders than mice that ate food raised with chemical fertilizers. ${ }^{83}$ A health magazine, Prevention, was launched in 1950, and in 1955 a small British company was started to sell books, and later vitamins. The 29 
death of Rodale's brother, and the consequent need to buy out his widow's 50 percent share in Rodale Manufacturing, put Rodale Press under great financial pressure, as it could no longer be cross-subsidized by the electrical company, and in 1956 Rodale had to sell off his printing presses, and seek more advertising revenues. By 1958 Rodale’s Press sales reached \$2 million and it was finally commercial viable. In 1960 Rodale started a new publication, Compost Science, The Journal of Waste Recycling, sold to large firms and city governments concerned with disposing with waste. ${ }^{84}$

Into the 1960s, when the hippies and the counterculture discovered his methods, Rodale's readers were still primarily residential yard gardeners. ${ }^{85}$ Carson's Silent Spring was praised in the Rodale Press, and Rodale himself published a similar book two years later, Our Poisoned Earth and Sky. However Rodale's son Bob increasingly ran the company, while Rodale himself focused on writing plays, often focused on health issues, and poorly received by critics. The company also spent much of the 1960s entangled in a legal case with the US government concerning whether a Rodale publication called Health Finder had made deceptive claims in its advertising. ${ }^{86}$

A final formative figure in the United States was Alan Chadwick. He was a British expatriate who had developed his own gardening style which combined Steiner's ideas with those of a French intensive gardening method known as Permaculture. In 1967 he had been hired by the University of California Santa Cruz to create a Student Garden Project, where he transformed a steep hillside into a prolific garden working only with hand tools and organic amendments, a change on which it was eventually vindicated. Chadwick helped spur the organic gardening and farming movements in California. ${ }^{87}$ Chadwick and the Garden Project was a 
formative influence on a new generation of Californian organic farmers. These included Jonathan Frey, a pioneer of organic farms (see below), and Drew Goodman, who with his wife Myra co-founded Earthbound Farms in 1984 as a small raspberry farm, which grew as a pioneer of the organic packaged salad market. ${ }^{88}$

In Japan, Masanobu Fukuoka was an influential organic pioneer. He was born on the Japanese island of Shikoku in 1913 to a landowning family. His parents sent him to agricultural college. He almost died from acute pneumonia when he was twenty five, and during this experience came to the conclusion that "in this world there is nothing at all." During the Pacific war, while working an experimental agricultural station, he conducted comparative studies on the yields from intensively cultivated crops enhanced with chemical fertilizers and pesticides with those achieved from crops grown without chemical additives. After the end of the war he returned to what was left of his fathers lands, and began practicing the principles of "natural farming”, which involved restoring natural ecology. Over the following thirty years, as highly commercialized farming transformed the Japanese countryside, he had little contact with anyone outside his village, and devoted himself instead to what he later called "the road of a dilettantish farmer tilling a lost paradise." 89

During the 1970s the pioneers of organic farming finally began to make a much wider impact. In 1975 Fukuoka finally went public with a book called Shizen Noho Wara Ippon no Kakumei, which was translated into English in 1978 as The One-Straw Revolution. He not only introduced his principles of natural farming but put forward his understanding of how natural farming related to larger issues, warning how chemical-driven scientific agriculture would deplete the earth's natural fertility. The One-Straw Revolution established Fukuoka's international identity as a guru of natural farming. After 1979 he travelled extensively in the 31 
West and increasingly in developing countries. However Japanese agriculture itself remained uninterested in organic production.

Just before his death in 1971, J. I. Rodale had also begun to attract more attention. In May 1970, weeks after the first Earth Day, Rodale convened the first Organic Food Symposium in Allentown, Pennsylvania, which attracted 175 organic growers and owners of organic food stores. In December 1970 the US magazine Life featured the organic movement on its cover, estimated that there were 5,000 organic farmers in the US, and included a picture of the Rodale farm. Most importantly, in June 61971 the Rodales appeared as the cover story of the New York Times Magazine. The cover showed Rodale in a suit and tie, walking through a field on the farm, and described him as the "foremost prophet" of the organic movement. ${ }^{90}$

Recognition by the New York Times was important, but did not translate into an enormous break though in recognition for organic farmers. Even in U.S. states such as California were organic agriculture had taken hold, it continued to face dislike from many conventional farmers. Organic farmers faced major problems selling their products, forcing them to seek alternative distributors and retail outlets. Jim Cochran, who established the first commercial organic farm in California in 1983, later remarked;

“The organic movement evolved outside the conventional movement because the conventional movement didn't really want to be bothered with us much, and so we had a hard time getting our stuff into the distributors, or at least at a good enough price to make it worthwhile...so we had to develop our own markets pretty much customer by customer. We had to teach the people who worked in the produce department how to display the produce, how to handle the produce, how to tell our story, how to price it.” 91 
Myra Goodman faced the same challenge when Earthbound Farms began selling packaged organic salads in 1986. She later remembered,

" We sold in local gourmet markets, it was hard at first because they would only take our salad as 'guaranteed sales' which meant they wouldn't pay us anything unless our salads sold...then we went to hotels and restaurants locally to introduce our salad in a bag concept.. at the beginning everybody was really suspicious, there was definitely an education process." ${ }^{92}$

There was a need for substantial changes in natural foods retailing and distribution for organic agriculture to gain greater scale. One solution was "community-supported agriculture” (hereafter CSA). CSA began in the early 1960s in Germany and Switzerland when groups of consumers and farmers formed cooperative partnerships to promote ecologically sound, and socially equitable, agriculture. Many of these ventures were heavily influenced by Steiner's ideas. In 1984 Jan Vander Tuin, who had co-founded a community-supported agricultural project named Topanimbur, located near Zurich, Switzerland, introduced the concept to the United States, through a contact with Robyn Van En, who had a small farm in Massachusetts. Beginning with a small apple orchard, she became a passionate advocate of the system in North America. ${ }^{93}$ A fundamental premise was that growers and consumers shared the risks and benefits of food production, with members paying at the onset of the growing season for a share of the anticipated harvest. Once harvesting began, they received weekly shares of vegetables and fruit, in a vegetable box scheme.

CSA projects spread particularly on the US's West Coast. Among the most prominent exponents in California was Michael Ableman. Abelman had become involved in a southern Californian farm commune during the 1970s, before he took a job grafting orange trees at Fairview Gardens, near Santa Barbara. When he joined, this was remnant of a much larger farm 
established in the 1890s, which had become surrounded by suburban developments. Ableman saved the 12-acre farm from real estate developers in 1994, and it became a model for CSA agriculture. ${ }^{94}$

\subsection{Natural Foods after World War 2}

The health and natural foods business slowly developed alongside organic agriculture after 1945. There was considerable continuity from the interwar years. In the United States, Forest Shaklee emerged from retirement, resumed being a nutritionist part-time, and developed a new philosophy which he called "thoughtmanship". In 1956, with his two sons, he launched Shaklee Products. The first product was a protein-lecithin supplement of his own invention, sold under the name Pro-Lecin Nibblers. Then added an herbal laxative called Herb-Lax. In 1957 a Vita-Lea, a multivitamin was launched. The new marketing strategy involved recruiting independent contractors and offering incentives which rewarded them for sales. Within a decade it was all over California. In 1965 there were 13,000 distributors. ${ }^{95}$

The same continuity was observable in Germany. After the end of World War 2, there were about 500 Reform House shops still in business in Germany. They found themselves split between West and East Germany, but managed to unite into a single trade organization, the Neuform Vereinigung Deutscher Reformhäuser, in 1950. During the 1950s the organization continued to grow, although with tensions between new entrants and older firms concerning whether products were being made in accordance with the ideals of the movement. There were also a new demand from drug stores and specialty food stores for the products of the reform movement. It did not bar these stores from selling its products, but put in place stricter conditions of entry, requiring the owners of stores who wanted to expand into life reform to take an introductory course in life reform for a fee, complete a two- to six-month long unpaid 
apprenticeship in a Reform House shop, and pay membership fees once accepted into the trade. As competition from products sold in department stores and supermarkets emerged, the Reform trade increased the number of specialty retail store locations where its products were sold, and also began to sell decorative cosmetics in the 1970s, though there was strong opposition in the industry to selling beauty products that went beyond skin care, such as lipsticks. ${ }^{96}$ Through to the end of the 1970s the Reform House shops and direct marketing dominated organic sales in Germany. ${ }^{97}$

Everywhere the growth of natural foods business faced challenges arising from both securing supplies of products and building distribution networks and outlets. In the United States, a new generation of entrepreneurs emerged from young radicals who came of age during the 1960s and 1970s were important actors in beginning to address these issues. They were part of the counterculture, and many had been active in the anti-war, women's, and civil rights movements. Many of them became active environmentalists. These entrepreneurs were motivated to enter the food business by the realization that food crops grown since the 1940s were increasingly produced with the aid of chemical pesticides and fertilizers. They read Silent Spring and were concerned about the risks posed to humans and the rest of nature by introducing chemicals into the food chain. As Frank Ford, the founder of Arrowhead Mills proclaimed: "food is over processed, laced with chemicals, and devoid of nutrition.” Ford, like the movement he came to represent, also aligned himself with those who argued that the extraction and use of the planet's resources had reached an unsustainable level. Conventionally produced food, Ford held, "consumes precious energy when we produce it and weakens our health when we eat it."98

Ford started his food retail business on his farm in Hereford, Deaf Smith County, Texas. A 1955 graduate from Texas A \& M University, Ford majored in agriculture at college, and won 35 
the school's prestigious award 'Outstanding Agricultural Graduate'. Most winners of the award went on to work for a large food company, or took posts in government agencies. Ford, after a brief military career, chose another route, heading back to the Panhandle to become a so-called “dirt farmer.” In 1960, he founded Arrowhead Mills as a “farm-to-market company.” Ford and his wife Marjorie began with a stone-mill, a 1939 tractor, and an old railroad car as their office. ${ }^{99}$ Arrowhead Mills was among the first US firms to package organic products such as flour and bulk grains.

Ford decided literally to farm in the dirt. He declined to use herbicides or sell grains to the big food companies, which ground it into white flour and added chemical preservatives to the flour. ${ }^{100}$ He put his life savings down on a tractor and set out to farm organically grown corn and wheat. With a stone mill he ground his harvest and delivered it to local stores from the back of a pick-up truck. As word spread about organic farming, health stores in other parts of the United States began ordering stock from Arrowhead Mills. ${ }^{101}$ In 1967, the company became profitable. In the late 1970s his sales were $\$ 10$ million, and sold 300 products. It was the largest distributor of organic foods in the U.S., and the Deaf Smith label the company used had gained international recognition as being a guaranteed chemical free product. ${ }^{102}$

Ford himself had not started out as a deliberate natural foods pioneer. In retrospect, he remembered "I was not on a crusade. I had never even heard of the word organic. I just knew in my heart that God's earth would take care of you without any help from man.” ${ }^{103}$ Alongside the natural food business, he also became an activist on issues of world hunger, excessive energy use, and the use of chemicals. In 1973 he succumbed to depression. After an unsuccessful suicide attempt, Ford was born again as a Christian, and his company took on an increasingly religious 
dimension. New Harvest, published by the Christian publisher Harvest Press, was Ford's “spiritual testament” and account of his journey. ${ }^{104}$

As Ford struggled to move his Texas Panhandle business out of the red, a group of natural foods entrepreneurs entered the industry out of hippie communes in San Francisco and other alternative communities like the New Alchemy Institute in Vermont. In 1967 Fred Rohe, a leader of San Francisco's hippie community in Haight-Ashbury, Paul Hawken of Erewon in Boston, and Frank Ford came into contact. "It was a very exciting time”, Ford later recalled, "and the three of us spent every possible moment traveling across the country, speaking to small groups of people, and sitting up to the wee hours of the morning plotting the natural-foods revolution." ${ }^{105}$

These new entrepreneurs recognized that traditional, natural foods had become scarce in the market, even in so-called health food stores. Since natural food itself was no longer easy to obtain, they had to change the system of the making food, and they had to build distribution networks. While Ford started out as a farmer, Paul Hawken and Fred Rohe spent the early years of their businesses trying to locate suppliers of natural food. The early business model for selling natural food in the U.S. market combined wholesale distribution with setting up natural foods retail stores and catalogue sales to reach customers outside of the major urban areas where the natural foods and health food stores were clustered such as Boston, Boulder, San Francisco, New York, and Ann Arbor.

The first distributor of natural foods in the United States originated in 1966 when a small below-street level macrobiotic and natural foods store opened in Newbury Street in Boston. Aveline and Michio Kushi were the founders of Erewhon. The macrobiotic movement, which emphasized the benefits of the traditional Japanese diet based on unrefined foods with very little 
or no milk or animal foods, came to the US via Japanese teachers of this philosophy, especially George and Lima Ohsawa, and later Michio and Aveline Kushi in Boston and Herman and Cornellia Aihara in Chico, California.

Erewon was the first store of its kind in America and it became a model for many other similar natural food stores across the nation. Erewhon sold several soyfoods, mainly miso and shoyu, purchased from suppliers in New York. In 1967 the 21-year old Paul Hawken took over the management of the store, changed the name to Erewhon Trading Co, and started to expand the business. Hawken, who would in time become an influential American environmental activist ${ }^{106}$, had grown up in Berkeley, California, where he encountered the ideas of Emerson and the transcendentalists before being expelled from high school, and working with Martin Luther King's civil rights movement before arriving in Boston. The shop started to import foods from Japan, initially from Muso Shokuhin. The initial orders contained red miso and natural shoyu. In 1968 Hawken also established his first supplier of organically grown grains, a wheat farmer in Montana. By 1973 Erewhon, which pioneered the concept of contracting with farmers to produce organic crops, had contracts with 57 farms in 35 states to provide the company directly with organically-grown foods. Such contracts were critically important to expanding organic agricultural production.

In 1969 Hawken left for Japan, staying for nine months, arranging for individual packaging of products that were formerly imported in bulk, and finding new items for Erewhon to import. He visited suppliers, and studied Japanese language and culture. In 1969 Aveline Kushi herself moved to Los Angeles where her youngest son underwent traditional Japanese bone massage therapy, and she established the first macrobiotic study house. In 1973 Hawken resigned from the venture. Four years later a legal case launched by Erewhon against a number 
of natural food stores resulted in such huge legal costs that in 1981 the firm went bankrupt. ${ }^{107}$ Hawken himself had moved on to Scotland, where he wrote a study of a remote ecological and spiritual community which had started several years previously called Findhorn. ${ }^{108}$

Starting in 1969 a number of macrobiotic and/or natural foods companies grew into distributors following the models established by, and with help from, Erewhon. These included Eden Organic Foods in Ann Arbor, started by Bill Bolduc, Food for Life, started by Bill Tara as a retail store in a Chicago office building, and Janus in Seattle, started in 1972 by George Gearhart and Blake Rankin. These macrobiotic distributors had a strong influence on the numerous other non-macrobiotic natural food distributors which developed, but the US natural foods sector continued to be quite sharply divided between the macrobiotic and non-macrobiotic strands.

There was a noteworthy clustering of entrepreneurial activity in the emergent natural food sector. One of the clusters was in Boulder, Colorado. Celestial Seasonings, an herbal tea maker, was Boulder's first enduring entrant into the natural products industry. The founder, Mo Siegel, the son of a Protestant father and a Jewish mother, had grown up on a dairy farm in Colorado, where his parents had moved when he was one. ${ }^{109}$ Siegel's mother was killed by a drunk driver when he was only two years old. His deeply religious but unconventional father was left to raise Siegel and his two siblings alone. Like so other green entrepreneurs, including Paul Hawken, Siegel suffered from serious illness, in his case asthma, though this did not keep him from embracing an active life of hiking the hills around his family’s farm. ${ }^{110}$

Siegel developed unconventional ideas about religion and embarked on a quest for deeper spiritual meaning. This quest intensified during his teens, when he attended a monastery and college preparatory school in Cañon City as a boarding school student. ${ }^{111}$ In 1969 he was 39 
introduced to the mystical Urantia Book by a girlfriend. After putting it aside for a year, he started reading it, and became obsessed, hosting weekly Urantia Book study groups at his home. ${ }^{112}$ The book, he later observed,

"made me examine my values and commit myself to doing something worthwhile with my life. After college, studying and peace marches were replaced by the ordinary tasks of living: making money and raising a family. After studying the teachings in The Urantia Book, I knew that it would feel selfish and wasteful to simply focus on material success. So, as a young man, when I began thinking of what I could do to make a living, I immediately turned to the health food industry. I was adamant that whatever product or service I sold should be healthy and make a positive difference in people's quality of life. Growing up in Colorado, I had developed a love for hiking and spending time in the mountains. Not long after I read The Urantia Book, I decided to start collecting the herbs that grew wild in the canyons and valleys of the mountains around Boulder. With the help of friends, I collected and dried 500 pounds of my first blend, called Mo's 36 Herb Tea ${ }^{\circledR},{ }^{\prime 113}$

Siegel found a steady buyer when a health foods store called Green Mountain Grainery opened in $1970 .{ }^{114}$ After the Green Mountain Grainery succeeded in selling the whole lot of Mo's 36 Herb Tea, it began to be distributed more widely to natural foods and health food stores. ${ }^{115}$ Riding on this success, the best-seller Sleepytime Herb Tea was conceived and launched in $1970 .{ }^{116}$ In 1971 the company started sourcing herbs internationally. Siegel started travelling all over the world to source herb crops. By 1975, the company had 50 employees. Direct-to-source purchasing started, and botanicals were now sourced from 35 countries. International sales began in 1977. In 1980, diversification began with the creation of the Mountain Herbery hair care products company. ${ }^{117}$ 
A cluster of other natural foods companies formed in Boulder, including retailers. Mark Retzloff and S.M. "Hass" Hassan, for example, opened Pearl Street Market in Boulder in 1979. Retzloff and Hassan were followers of the Indian "Guru Maharaj Ji" and had met in 1973 at a gathering in Houston for the guru's Divine Light Mission, which was headquartered in Denver. Steve Demos himself had embraced Buddhism while hitchhiking around India for four years. He came to Boulder to study Tai Chi Chuan, a combination of meditation and yoga, but also to prove that a business model built on environmental stewardship, social responsibility and authentic food could work better than pure capitalism. Wild Oats was founded in 1987 by Michael Gilliland and his wife, Elizabeth Cook, who purchased the Crystal Market vegetarian natural foods store in Boulder. The business succeeded so well that within four years the company opened its first supermarket-sized store in Santa Fe, New Mexico. In 1992, it was renamed the Wild Oats Vegetarian Market. ${ }^{118}$

The establishment of supply networks and distribution systems, and the creation of brands, seen in the United States from the 1960s had strong echoes in Europe. In 1957 a Belgian entrepreneur called Pierre Gevaert started an organic foods store called Lima. Although he started in Belgium, he soon opened the first organic store in France. Gevaert had come into contact with the founder of macrobiotics, George Ohsawa, and he started the sale of a few Japanese products names after George Ohsawa's wife Lima. ${ }^{119}$

During the mid-1960s another venture called Solsain was planned in 1966 in Paris by Roland Chevriot and Claude Aubert, who were associated with the founding members of N \& P. Chevriot was an engineer with no agricultural training, who became a philosophical adviser to the founders, whilst Aubert was an agronomist who provided technical training for farmers. The original goal to "import" natural foods from rural areas to Paris, and to educate the urban 41 
population about the difference between organic and traditionally grown products. ${ }^{120}$ The name Solsain, or healthy soil, was registered as a trademark, but both men were involved in radical politics, and building a business was not their primary interest. As Aubert later remarked,

"We were militants, we really were not interested in a business venture, and the profit making part of it did not appeal to us. We ended up selling organic vegetables and fruits here and there, but it never really took off as a fully fledged business. We had neither the funds nor the will to launch a business venture.. we wanted to stay in the non-profit world."121

By the 1980s these and other ventures had made limited progress in France, compared to the northern European countries. Aubert, after a decade of trying to advise French farmers on organic techniques, decided to follow the path of Geffroy and Rodale and moved into publishing. In the mid-1980s he founded a non-profit publishing house called Terre Vivante aimed at providing a scientific framework for organic farming in the country. ${ }^{122}$

\subsection{Standards}

A persistant obstacle to the development of the natural and organic foods had been the lack of certification standards. As postwar tensions within Germany's Reform movement indicated, the issue of what qualified as a legitimate product was a major problem. Many of the people active in natural foods had strong ideological views, and they argued intensely between each other. As important, for the development of the market segment, was that it needed an identity which made clear its value proposition, and which made clear what products were legitimate, and what products made claims which were not legitimate. It was, however, no easy matter to define acceptable standards for products made and sold in small numbers by often individualistic farmers or entrepreneurs. 
The biodynamic movement in Germany were pioneers in seeking to set standards. The trademark Demeter was registered in 1931, and awarded to farmers who were inspected and met certain standards. Later, in 1955, a more formalized structure was created for the use of the Demeter label. The movement of Hans Müller in Switzerland began developing norms from 1946. In 1967 the Soil Association published its first set of organic standards for Britain. In 1972 Nature et Progrès released its first set of guidelines for organic agriculture in France. However the institutionalization of the organic movement was never easy and there were frequent tensions in associations, and over the setting of standards. In post Austria, to give one example, where organic farming had got off to an early start in the interwar years, there were multiple organic farming associations. In 1984 an attempt to bring them together in one umbrella organization, ARGE, floundered because of internal conflicts. It had to be re-launched in 1990, only to have dissenters set up an alternative umbrella organizational four years later. ${ }^{123}$

In the United States, the first standards came from firms rather than associations. During the mid-1960s Walnut Acres, and another integrated manufacturer, Shiloh Farms, created inhouse programs to ensure that the ingredients they purchased were grown in accordance with their own standards. Walnut Acres only abandoned its certifying and labeling program in 1992, when it accepted nationally recognized standards.

In 1973 a group of California growers formed one of the first independent certification programs, the California Certified Organic Farmers (CCOF). This had emerged from the efforts of scattered individual farmers, and was initially supported by Rodale Press. The volunteer organization, which initially had 54 grower members, had monthly meetings, and visited farms to check that crops were being grown organically. ${ }^{124}$ The California Organic Food Act of 1979 43 
was signed into law. It was a state-mandated local program, but there was no budgetary appropriation given to the law for enforcement. Infractions had to be taken up in the courts by organizations like CCOF. During the 1980s every complaint to the California Department of Food and Agriculture concerning infractions came from the CCOF, which was only able to hire its first staff member in 1985. In 1990, after 20 months of lobbying, the California Organic Foods Act was passed. Third-party certification was still voluntary under the new law, but CCOF's standards were used as the foundation for the COFA. ${ }^{125}$

In 1985 the Organic Trade Association was formed as a trade association to represent growers, distributors and processors in the US and Canada, and it began to develop certification standards. In 1990 the US Department of Agriculture (USDA) formed a National Organics Board which began developing over the following decade a nation-wide definition of organic which resulted, in 2000, in the issue of National Organic Standards which required anyone involved in growing and processing organic food to be certified by the USDA. The standards prohibited the use of pesticides and synthetic fertilizers, regulated crop rotation practices, and the genetic manipulation of crops and animals. ${ }^{126}$

The pioneers of organic farming and natural foods had long manifested an international vision. Lady Eve Balfour, for example, had been eager from the beginning to make the Soil Association international. She undertook tours of North America, visited Australia and other European countries. By the mid-1950s the Association had 3,500 members from more than 50 countries. ${ }^{127}$ At the Versailles conference in 1972 the president of Nature et Progrès, Roland Chevriot, took the initiative to launch the International Federation of Organic Agriculture Movements. (IFOAM) Although Chevriot spoke no English, he was committed to a global vision 
for organic foods. ${ }^{128}$ He was joined by four other organizations, including Lady Eve Balfour representing the Soil Association, the Swedish Biodynamic Association, the Soil Association of South Africa, and Rodale Press of the United States. ${ }^{129}$ The founders intended that the federation would meet what they saw as a major need: a unified, organized voice for organic food, and the diffusion and exchange of information on the principles and practices of organic agriculture across national and linguistic boundaries. ${ }^{130}$

It proved a complex matter to develop international standards. IFOAM initially had no full-time staff and operated out of borrowed space from the French organization. In 1976, the organization’s budget was only $\$ 6,000$. Each national organization had its own ideas concerning standards. Some organizations did not like standards at all. The Japanese organization, for example, maintained that organic agriculture was based on a face to face relationship between farmers and consumers that did not require standards. Yet by 1980 the first draft of organic standards was in place. In 1986 a loan from its then outgoing General Secretary, allowed the organization to hire its first full time employee. ${ }^{131}$ In that year the organization moved to a new headquarters in Germany. ${ }^{132}$

During the 1980s European governments became involved in standards and, somewhat later, in providing subsidies to organic agriculture. In 1986 France became the first European country to adopt organic standards, which were based on those drafted by Nature et Progrès in 1972. The engagement of governments with standards reflected, in part, the success of lobbying by advocacy groups. In Britain, for example, during the early 1980s the Soil Association shifted from its research and education roles to a more proactive lobbying stance. In 1983 it launched a consumer campaign aimed at raising awareness of organic food, which it hoped would result in consumer pressure on the government to become involved in standards. In the following year the 45 
British government established the Registry of Organic Food Standards as the "certifer of certifers. ${ }^{, 133}$

In 1992 the EU produced its own first set of organic standards, although it proved no easy matter to reconcile them with national standards. In France, for example, the government modified its own standards in 1995 to bring them in line with the EU ones. At the same time they dropped Nature et Progrès as the certifying organization. This displaced activists who considered that the EU standards were a step backwards. Nature et Progrès responded with a new set of guidelines and their own certification standards, in 1995. The group became known as the “boycotters", representing organic farmers who refused to obtain the government certification. ${ }^{134}$ Meanwhile, as these conflicts developed, the EU launched subsidies to organic agriculture in the mid-1990s, and these and national subsidies became substantial drivers of organic agriculture. ${ }^{135}$

\subsection{Coming of Age and New Challenges}

A decade after the first natural foods stores began to spring up in cities in California, Colorado, Massachusetts, and other states with concentrations of liberal, college-educated and countercultural young Americans, John Mackey started a business that became the highly successful natural and organic food retailer Whole Foods. Founded as the Safer Way food store in 1978 in Austin, Texas, Mackey and his girlfriend Rene Hardy borrowed \$45,000 from family and friends to open a natural foods store. Like many of the natural foods pioneers who started their business before him, Mackey had joined the counter-culture movement in the late 1960s. He had dropped out of college six times, and after leaving college lived in a commune. He studied eastern philosophy and religion, yoga and meditation, and ecology. The new store struggled, but after two years Mackey persuaded his father and a customer to invest $\$ 25,000$ to 
open a bigger, 10,000 square foot, store called Whole Foods Market. He persuaded several smaller local organic grocers to join him, and the venture took off. ${ }^{136}$

Mackey combined a strong sense of social mission with an equally strong desire to grow and make profits. Expansion began in 1984, to Houston and Dallas, and next to New Orleans. Mackey opened in California in Palo Alto in 1989. From that time on, the company expanded rapidly by opening new stores, and by acquiring other natural foods stores and chains. By 1991, the company operated 12 stores with total annual sales of $\$ 92.5$ million. Whole Foods went public in 1992. It became the first countercultural natural foods stores to conduct an IPO. This provided the financial means to begin making further acquisitions. In that year Wholefoods acquired Bread \& Circus, a well-known New England chain of stores. Mackey used such acquisitions not only to grow his business, but to learn. While Whole Foods began by selling dry goods, which were easy to stock and sell, Bread \& Circus had a successful and profitable meat and seafood department, which he quickly adopted in his other stores. ${ }^{137}$

Mackey’s emphasis on growth and profits set him apart from most all his predecessors in natural and organic foods. He asserted publicly that there was no contradiction in combining a social agenda with seeking profits. "Wall Street isn't going to corrupt Whole Foods Market, he told one journalist in 1992. "We're going to purify Wall Street." The company gave 5 per cent of its profits to charitable causes, and empowered its staff to work in teams which did their own buying, pricing, hiring and firing. Mackey resolutely opposed unionization. After 18 months outside his Berkeley, California store, he noted "We're not antiunion. We're beyond union." ${ }^{138}$

Mainstream companies also entered the natural foods market. As health and natural foods rose up consumer preferences, long-forgotten heritages were rediscovered. In 1984 Kellogg 47 
became the first US mass consumer food manufacturer to display a health claim on its product packaging, when it linked the consumption of its high-fiber cereal brand All-Bran to a reduced cancer risk. ${ }^{139}$ In the United States, in 1988 a health scare related to the use of Alar, a growth regulator used to ripen apples, caused a two-thirds growth in American organic produce sales in one year, and also resulted in many supermarkets, especially in California, stocking organic fruit and vegetables for the first time, although most withdrew shortly afterwards because of consumer resistance to the much higher prices and irregularity of supplies. ${ }^{140}$

Big food companies began acquiring pioneering brands, such as Celestial Seasonings. This company had become the market leader in herbal teas in the United States, and even closed in on the leaders of the overall black tea market by the 1980 s. ${ }^{141}$ The consumer goods giant Unilever had to mount a fierce battle to protect its Lipton Tea brand in the United States from the newcomer. ${ }^{142}$ Celestial Seasonings attempted an IPO in 1983, but it had to be cancelled after a product recall. ${ }^{143}$ In 1984, the company was acquired by Kraft Foods, one of the US's largest food companies. ${ }^{144}$ Siegel stayed on as president of the company, but a few years later, in 1986, he decided to retire to travel the world and do humanitarian work. ${ }^{145}$ By 1987, when Kraft tried to sell Celestial Seasonings to Unilever, Celestial Seasonings held the leading position in the U.S. herbal tea market with 52 percent of sales. Lipton had entered the herbal tea market, and held 32 percent of the American market. After the Unilever acquisition was blocked on anti-trust grounds, Celestial Seasonings was acquired by Vestar Capital Partners in a leveraged buy-out in 1988. ${ }^{146}$ The company's management was left intact, and Siegel returned to run Celestial Seasonings in 1991 as CEO and Chairman of the Board. ${ }^{147}$ Celestial Seasonings went public in 1993. ${ }^{148}$ 
During the 1990s, the rising demand for organic food encouraged large food companies to invest in the sector. "No longer the cuisine only of sandal-clad environmentalists, organic food is coming of age”, an article in The New York Times noted in 1996. "It is clearly big business."149 It might more appropriately be described as a bigger business than it had been twenty years previously. In 1980 the USDA, in its first study of organic farming, believed that there might have been at least 24,000 organic farmers in the United States. ${ }^{150}$ In the early 1990 s perhaps only 0.1 per cent of U.S. agricultural land was devoted to certified organic production. The farms were smaller than in countries such as Germany, and the farmers disproportionately welleducated, with about half having attended college. ${ }^{151}$ Between 1992 and 1997 the total certified organic farmland grew 44 per cent, raising the organic share of crop land to about 0.2 per cent. ${ }^{152}$

By the turn of the century, the amount of organic food sold in the United States had reached $\$ 6.5$ billion, which represented around 1 per cent of total food sales. Nearly one-quarter of this, or $\$ 1.45$ billion, was comprised of fresh fruit and vegetables. Natural food stores accounted for just under 70 per cent of these sales, whilst mainstream supermarkets accounted for the remainder. There were about 12,250 natural foods stores in the United States by then, of which the two largest chains, Wholefoods and Wild Oats accounted for around 220, and the remainder with primarily independent retail stores. There was considerable unevenness in the location of such stores. The state of California accounted for nearly 2,000 of the total. There were also over 700 each in Florida, Texas and New York. ${ }^{153}$

In Europe, as in the United States, there was wide geographical variation in the market for organic products, and there was also wide variation between countries in distribution channels. In many countries, including Britain, France, Italy, and the Netherlands, organic sales 
were still around 1 per cent of the total food market in 2000. In France, which had been a pioneer in organic standards, the growth of the organic food market stalled in the 1990s. Until the early 1990s organic foods had been primarily sold in specialized natural foods stores, including chains such as Biocoop and La Vie Claire, but by the end of that decade they accounted for about 29 per cent of total sales. Supermarkets accounted for 38 per cent of sales, bakers for 17 per cent, and direct sales 16 per cent.

In Britain, organic sales also only represented about 1 per cent of the total food market, but the distribution outlets were different. Large supermarkets had started stocking natural and organic foods quite early. Among the largest supermarket chains, Safeway began stocking fresh organic fruit and vegetables in 1981, followed by Asda in 1986 and Sainsbury in 1987. The appearance, and publicity, given to the outbreak of "mad cow disease" in Britain during the 1990s helped the mainstreaming of organic products. By 2000 supermarkets accounted for around three-quarters of organic sales. ${ }^{154}$ In the Netherlands, where the organic food market also remained relatively subdued, there was also some growth during the 1990s with supportive government measures for organic agriculture, and the entry of supermarkets in the business. However, it was only in 1996 that the largest Dutch supermarket, Albert Heijn, started stocking organic products. ${ }^{155}$

In parts of northern and central Europe, the relative importance of organic food sales became higher. In Austria and Switzerland organic food represented 1.8 per cent and 2 per cent respectively of the total food market. In Germany, where organic farming comprised over 3 per cent of total agricultural land, the overall size of the organic food market was unclear, but believed to be much larger than in Britain and France at around 1.5 per cent of the total food 50 
market. Organic vegetable sales were 2.6 percent (by value) of the total fruits and vegetable market in 1999. Unlike Britain, Germany’s 2,000 natural food stores accounted for over onethird of the market, and supermarkets less than a quarter. On-farm sales and market stalls also accounted for one-fifth of organic sales. ${ }^{156}$

The growth of the Danish organic food market shows how a virtuous circle involving firms, retail channels and governments could shape and grow consumer demand. As in other European countries, there was a long tradition of organic farming - a Bio-dynamic Association was founded in 1936 - but it remained quite marginal. In 1981 a Danish organic association was founded. ${ }^{157}$ In 1982 the Danish consumer cooperative FDP (Fællesforeningen for Danmarks Brugsforeninger), a large Danish retailer, began selling organic carrots produced from a radical community of intellectuals and students. The co-operative, owned by its members, felt this, at the time, radical experiment was a response to the worries of their members about pesticides. In 1987 FDP also began selling organic milk. In a culture where milk-drinking was widespread and important, this was an important step, as milk was given to children to nourish them. Although organic milk was sold at a premium to conventional milk, it was in absolute terms not hugely expensive for many consumers, reducing one potnetial obstacle to purchases. Organic milk became an entry point for Danish organic consumers. ${ }^{158}$

In 1989 lobbying by organic farmers, the FDP and others led to the Danish government establishing a Danish Organic Food Council in which all the stakeholders met regulary to discuss issues, and to the first official label for organic products. The red "Ø" label, which showed that a product was state-certified organic, became a significant force in establishing the credibility of organic products. ${ }^{159}$ 
Four years later FDP's Super Brugsen chain lowerd the retail price of organic food products by up to 40 per cent, and decided to sell organic products throughout the nation, not only in the capital city of Copenhagen. There were conflicts within the organization about taking the step, but the supporters of organic foods were faciltated by the democratic nature of the organization in which, in the last resort, commerical decisions could be made without regard to whether they would be profitable, at least in the short term. The cutting of prices drove sales of organic milk up nearly 500 per cent over the following years. ${ }^{160}$ Between 1996 and 2000 organic farmland increased from 46,171 hectacres to 165,000 hectacres. By 2000 total organic farmland accounted for 6.2 per cent of total Danish farmland. By that year FDP and other large supermarkets accounted for around three-quarters sales of organic food, which represented between 2.5 and 3 per cent of the total Danish food market. ${ }^{161}$

While the decision of Denmark's largest retailer to cut prices was a significant factor in creating a much larger organic consumer market, there were also other significant entrepreneurial actors. Among the most important was the development of organic food box schemes led by Thomas Harrtung and Soren Ejlersen. In 1984, the 23-year old Harrtung had inherited his parents farm in Jutland, or rather country estate as they lived and worked in Copenhagen. He had studied at Copenhagen’s Agricultural University, but had intended to work in an aid agency before his parents died early. He introduced sustainable forest management, which he had studied at university, but farmed the rest of the farm conventionally until 1994, when he began noticing the disconnect between his forest management and the rest of his farm. He had come into contact with a wider range of organic ideas through participating in various government working groups, but a real turning point came in 1996 when he attended the IFOAM scientific conference in Copenhagen. He heard speeches by Michael Ableman, as well as other 52 
prominent North American organic figures, Wes Jackson and Jan Pigman, and became inspired by the idea of CSA. These insights were combined with a grwoing religious faith, as his New Age beliefs came to "happily nest in the Lutheran protestant church." 162

Harrtung launched a co-operative at his farm in the following year, as did Soren Ejlersen. However a number of decisions then changed the shape of the business. Harrtung and Ejlersen brought their farms together and, concerned about slow and cuatious decision-making of their co-operative, took the business private and launced the firm of Aarstiderne (or Seasons) in 1999. They stopped focussing on their local markets, and began taking boxes of their products to Copenhagen, where the major market was. From the beginning each box also included menus They also introduced an innovative system of ordering by internet. In 1999 Harrtung had attended the IFOAM scientific conference held at Basel, and been on the same panel as Alexander Schwedeler, who was then setting up a venture capital fund for Triodos Bank, the largest sustainable bank in Europe. This led to Triodis taking a 20 per cent stake in the bank in 2001 for $\$ 2$ million, providing the funds needed for expansion. ${ }^{163}$

The new century began, therefore, with considerable variations in the relative importance of organic foods consumption between geographies. These variations reflected the success, or otherwise, of businesses in making the case for organic foods, in creating attractive brands, and building supply and distribution networks. In every country, organic sales had begun with niche and ideological actors, who were eager to propagate their wider ideas alongside their organic fruit and vegetables. This confined the growth of the market, and scaling up the size of the businesses was the key to expanding the organic market share. In the United States, large organic retailers like Wholefoods and Wild Oats built the market from the 1980s by offering 
consumers attractive and reliable products. However, the willingness of conventional retailers, such as the large supermarkets in Britain or FDP in Denmark, to sell organic products could also be decisive in driving increased sales. The willingness of such firms to do this in turn reflected exogenous factors. German's long-established Reform tradition, for example, provided a basis for the more modern growth of the organic market. The importance of the organic market in California may have reflected wider environmental concerns among elements of its population. Governments were important too. The Danish government certification of organic products was an important part of the legitimization of the category. In the Netherlands, widespread belief that the government food safety standards were effective may have reduced demand for organic products. This may have also been one factor in reducing the demand for organic products in Norway too. In contrast, in Britain the huge publicity given to "mad cow disease" influenced the willingness of conventional retailers to sell organic food. ${ }^{164}$

\subsection{Organic Wine}

The history of organic wine has parallels with agriculture and food more generally, but it developed later, and proved much less successful. It developed out of the broader organic movement, but definitional issues concerning what was, and was not, organic, proved much more challenging. This lack of clarity, in turn, hindered the growth of the market.

The first organic vineyards may have started in Germany, but by the mid-1970s there were still fewer than 20 organic vineyards in Germany, with less than one hundred hectares of land under cultivation. In 1977 producers organized an association, Stiftung Ökologie \& Lanbau, to bring together organic wine producers from Germany, as well as France and Switzerland, in order to exchange information on the subject and make it accessible to others. Following this, the German association published a pioneering handbook on organic viticulture. ${ }^{165}$ 54 
It proved no easy task to develop the organic wine market. In 1983 Ursula and Erich Hartl established Germany’s first commercial enterprise to sell organic wine. Erich had grown up in rural Bavaria, and worked in the conventional restaurant and catering business. Becoming more concerned over time about the use of fertilizers in foods, the family decided to create their own business, in organic wine. The problem was supply. As he later remembered, "When we started in the early 1980s, they were no "catalog" of organic wines, and finding an organic wine maker in Germany was impossible. It was by accident that I came across this organic wine maker in France. I established a relationship with the producer, I tried his wines, I liked them and started importing them by small quantities in Germany. Then I traveled around to meet with organic wine makers, and started importing more and more wines from different countries."166

Finding organic wine producers was, as Hartl noted, only the start of the problem: "the "organic" or "bio" label were not allowed on wine bottles, when we started importing we couldn't go through the frontier with bottle carrying these 'organic' labels, we would have to drive along the border to find a hole in the system, we would negotiate with border officials until one of them would eventually let us through with our wines. And then even after we passed the borders we couldn't sell our wines in Germany until it went through a couple of tests which would usually take an additional 2 to 3 months, and at the end we couldn't even market our wine as 'organic' so we used the term "old fashioned wine” instead.” 167

By 1990 the situation initially encountered by Hartl in Germany had improved. There were almost 150 organic vineyards in Germany itself, and almost 350 five years later. It turned out, however, that there was faddish aspect to the market, and many early entrants pulled out. 
The number of organic vineyards in Germany had fallen back to less than 300 in 2000. This represented less than 1 per cent of Germany's overall wine production. ${ }^{168}$

In France, it was the region of Alsace which neighbored Germany where the first organic vineyards appeared. The pioneers included Patrick Frick, who took over his parent's vineyards and converted it to biodynamic methods in 1976. He was only one of three organic farmers in the region, and experienced financial difficulties as a result of the transition. This was of limited concern to Frick, who like many of the pioneers, was visionary and radical. "I wanted", he later observed, to "grow vines while respecting the land that our forefathers left us.. the land, but also water and air. It was a matter of conscience.” Like other pioneers, Frick also had a wider vision beyond wine. He joined the Green Party in France after it was formed in 1984, and was elected to represent his region in the regional council in the early 1990s. He became an active antinuclear energy campaigner. And he was also a "reaper" who was prepared to rip out genetically modified crops, albeit in a non-violent fashion. ${ }^{169}$

In the United States, the first organic winery was in California. In 1961 Paul and Beba Frey, both originally from Brooklyn, New York, went west with their young family and bought a farm in the inland part of Mendocino County near the town of Ukiah, 100 miles north of San Francisco. They planted vineyards and had twelve children. In the first decade of farming the Freys sold their grapes to wineries. In the mid-1970s, son Jonathan Frey and his wife Katrina trained under the organic gardening guru, Alan Chadwick at his Covelo, California site. The younger Frey spent a year and a half studying with Chadwick, and after trying unsuccessfully to develop an organic truck crop production on the family farm, switched to creating an organic vineyard. ${ }^{170}$ 
Frey and his wife faced multiple challenges. The industry was well-established in their region, and their business was seen as "a threat.. we arrived in the market claiming that our product was better and healthier than theirs."171 Their wine was more expensive than conventional wine, so initial sales were confined to niche groups who had already brought into the concept of natural products. In the absence of organic standards for wine production when the Freys started out, and until official certification was available, they simply wrote on their label "grapes grown organically". They began by selling to the handful of stores selling natural products to people following hippie or alternative lifestyles. During the 1990s, led by Jonathan's son Luke, the Freys converted to Biodynamic methods and became certified by Demeter. ${ }^{172}$

Organic wine faced unique challenges as it sought markets. There were fungus diseases which were difficult for organic wine producers to combat. ${ }^{173}$ Much more seriously, the concept of an all-natural wine ran into problems arising from the traditional use of sulphite or sulphur dioxide as a preservative in wines. This has strong antimicrobial and some antioxidant properties, which help to inhibit the growth of moulds and bacteria, stop oxidation and preserve a wine's natural flavor. If they are not added, there are preservation and taste issues because unlike organic food, wine is typically not consumed quickly, and may sit for years in bottles before being opened. Wine without sulfites was prone to bacterial infections that can make it smell or taste terrible. Wine without sulfites was also likely to oxidize quickly, again resulting in a loss of flavor.

Standards became more of a problem rather than an opportunity in organic wines. In the United States, following the Organic Foods Production Act in 1990, the USDA disallowed the use of preservatives such as nitrates and sulfites in wine, although because sulfites naturally 57 
occur in wine, organic wine was allowed up to 10 parts per million. In nonorganic wine, up to 350 parts per million were allowed. USDA-certified organic wine, then, often had, or was perceived to have, an unpalatable taste which dampened its appeal, even as other organic markets boomed. A confusing array of other categories, such as sustainable and "natural wine," developed, which had weak or even no official standards. Many winemakers settled for "Made from organically grown grapes." ${ }^{174}$

In contrast, EU legislation introduced in 1991 defined the cultivation rules that needed to be followed to make organic wine, but did not specify details about bottling and ageing or specify a definition of “organic wine.” Each European country was left responsible for certifying its own organic producers, and "organic wine” as such had no legal definition in the EU. The result was the European “organic wine” developed as a highly heterogeneous category. Many wine producers in France and Italy, which emerged as the largest European suppliers of organic wine, were attracted into the sector by EU subsidies and market opportunities in northern Europe and the United States, where most of the wine was sold. Case studies revealed a wide variation in wine-producing methods. ${ }^{175}$ It was not until 2012 that new EU legislation recognized the concept of “organic wine” or "Vin Biologique." The same legislation also recognized the category of “natural wine”, which was not organic, but contained lower sulphites than conventional wine.

\subsection{Emergence of the Natural Beauty Industry}

As in the case of food, beauty products in the pre-industrial age were all natural. Unlike food, however, natural did not mean safe. The organic and natural ingredients employed, such as the white lead widely used in cosmetics and hair dyes, were frequently hazardous. The creation of the modern industry from the nineteenth century, then, was based on the replacement of 58 
hazardous natural materials by the use of the apparently safer ingredients produced by the science of chemistry. The development of such products by the first generation of modern entrepreneurs in the industry was important in its legitimization, because previously the use of such products had not only often been regarded as morally dubious, but were also physically dangerous. Chemical ingredients also greatly expanded the repertoire of what could be offered to consumers. The fragrance industry was virtually transformed during the late nineteenth century by the development of synthetic scents which resulted in an explosion in the range of scents that a perfumer could utilize from the late 1890s. ${ }^{176}$

During the first half of the twentieth century the global beauty market expanded at a fast pace. Modern science and technology enabled products to be produced in ever greater quantities. Insofar as there was much criticism of the use of chemical ingredients, it was associated, as in the case of food, with right-wing ideologues. In Germany, it could be seen in some Nazi discourses which raged, for example, against the artificiality of Hollywood make-up, although these discourses were as incoherent as in most other matters. ${ }^{177}$ In the non-industrialized world, households and sometimes craftsmen continued to make traditional cosmetic, and medicinal, products from natural ingredients, which were the only ingredients available. However in the modern branded beauty industry, chemistry delivered whatever science there was in the burgeoning industry.

However safety concerns about the use of cosmetics began to emerge during the interwar years. Cosmetics had been excluded from the initial consumer safety legislation in the United States before 1914, but during the 1930s this exclusion began to be reconsidered. In 1933 the leading Hollywood studio released a newsreel advocating for changes to the 1906 Food and Drug Act which showed graphic descriptions of how several women had suffered corneal 
damaged from using an 'eyelash beautifier'. The product in question was an eyelash and eyebrow dye called 'Lash Lure' manufactured by a Los Angeles company Cosmetic Manufacturing Company. Lash Lure contained paraphenylenediamine, a coal tar dye widely used in the hairdressing industry. ${ }^{178}$ In 1938 the regulation of the cosmetics industry was placed under the jurisdiction of the Food and Drugs Administration, however there was no requirement for manufacturers of beauty products to submit information on cosmetic product ingredients with the exception of the statement of a warning that certain hair dye ingredients could cause injury. 179

When after World War 2 some of the first stirrings of a reaction against the use of chemical ingredients, and a return to using more "natural" ingredients emerged, it was not consumers nor their advocates who took the lead, but entrepreneurs. In the United States, in 1948 Emil Bronner, a scion of a soap making factory going back five generations to mid-nineteenth century Germany, founded what became Dr. Bronner's Magic Soaps in Los Angeles, selling liquid Peppermint soap and health food seasonings. Bronner, a trained chemist, was a passionate eccentric, whose campaigning for world peace across ethnic and religious divisions led to his temporary commitment to an insane asylum in Chicago in 1944. He found a more receptive home in Los Angeles, where - apart from making natural soap - he spoke in Pershing Square, a hot-bed of radical activism, about the need for world unity, for people to respect each other and the environment. He placed great hope on sees planetariums as being the temples of the future, where humanity could see how trivial their differences were in the context of the universe as a whole. ${ }^{180}$

In early postwar Europe it was often entrepreneurs with some formal education in biology rather than chemistry who were interested in the potential of natural ingredients. One of 60 
the first firms was Biotherm, started in 1950 by a French biologist who made a skin care product using a mineral water from the thermal springs at Molitg-les-Bains in the Pyrenees mountains. A dermatologist, Jus Julin, had identified the naturally occurring “Thermal Plankton”, unique to these springs, as a skin rejuvenator, and these were incorporated it into the Biotherm skin care range. $^{181}$

Four years later, in 1954, Edmund Georg Locher founded Juvena out of a pharmaceutical laboratory in Zurich. The new company began by using natural ingredients to create light skin creams instead of heavy fatty creams. ${ }^{182}$ In the same year Jacques Courtin-Clarins founded Clarins as a skincare company in France. As a young medical student, he had noted that when patients were treated for circulatory problems with massage, their skin looked better. He started a business with botanical body oils. Opening the first Clarins Institut de Beauté in Paris, he developed treatments and products for his salon using plant-based formulas first for the body, and then for the face, persuading celebrity actresses and ballerinas to endorse his skin treatments. By the 1970s, however, when the firm began to grow much more quickly, the focus had shifted to scientific research than botanicals per se. ${ }^{183}$

A more sustained interest in botanicals came from another French company, Yves Rocher. The founder was born in La Gacilly in Brittany, a rural province of France. The village was losing its population as people moved to the towns. Driven by the idea of creating jobs to revitalize the region, Yves Rocher decided to start a company in 1959 which focused on nature and feminine beauty. It began as a manufacturer of plant-based cosmetics distributed through mail order. A reliance on natural ingredients became a hallmark of the firm's products, which were distributed exclusively through mail order and its own shops. 
In France, also, whilst the perfume industry increasingly shifted to the use of synthetic ingredients, some firms resisted. In Grasse, a town which had supplied natural ingredients for perfumery for centuries, whilst most firms used some or all ingredients, the family owned firm of Robertet stood apart and remained dedicated to natural fragrance ingredients, even though they were more difficult to obtain and, therefore, more expensive. The company's research focused not only on developing new types of fragrances, but also on increasing the purity of its fragrances and the efficiency of its extraction process from natural ingredients. Under the third generation of the Maubert family during the 1960s, the company also diversified into making flavors, also from natural ingredients. ${ }^{184}$

As environmental issues gained more public attention in certain northern European countries, there were further entrepreneurial new entrants, even though the overall market was not great. In Germany, Dr. Rudolf Hauschka and Elisabeth Sigmund created the Dr. Hauschka brand in 1967, which used natural ingredients, especially from roses, and avoided synthetic additives. The Austrian-born Hauschka had met Rudolf Steiner in 1924, and founded his first WALA laboratory in 1935 to make anthroposophical medicines and remedies. ${ }^{185}$ In Sweden, a country where environmental concerns had become widespread, a new cohort of green entrepreneurs emerged. Pierre Roberts, then one of the leading Swedish beauty companies, launched Naturelle, a pioneering "natural” hair care brand based on the use of herbs. ${ }^{186}$ During the late 1960s the founders of Oriflame, a direct selling start-up, launched their business based on the use of Swedish natural herbs in the formulation of products, alongside a low perfume concept, no allergic reaction, and no animal testing. The founders were concerned about the environment, but by no means environmental activists, and saw the category as the opportunity 
to create a distinctive product, whose primary selling point was the avoidance of allergic reactions. ${ }^{187}$

In 1970 Tom and Kate Chappell created Tom's of Maine by making a phosphate-free laundry detergent. In 1975 they launched their first natural toothpaste on the market. Shortly afterwards their daughter was born, and they developed the first natural baby shampoo. Natural deodorants, mouthwash, and shaving cream soon followed, all sold through health food stores before 1990. Chappell had a master's degree from Harvard Divinity School, and the philosophy behind the business was decidedly Christian evangelical. Chappell's book, The Soul of a Business, promoted "common good capitalism" which he defined as "managing your business with multiple aims: the pursuit of profit and the intentional pursuit of goodness."188

A decade later Maine also saw the creation of another natural products company. Burt's Bees was founded by Roxanne Quimby and Burt Shavitz. Born mid-century in Cambridge, Massachusetts, Quimby developed an early passion for the arts and nature, and after receiving her BFA in Painting from the San Francisco Art Institute, moved to a small town in central Maine, where she used her life savings to buy her first 30 acres of woods, building a small cabin for her and her two twins. She met a beekeeper called Burt Shavitz, and started a business selling candles made from the beeswax created as a by-product of Burt's honey business at craft fairs. By 1991, when the company incorporated, it had begun to sell soap, perfume and lip balm cooked on a stove, and the firm was beginning to sell in upmarket department stores such as Marshall Field's. Profits were used in part to support environmentally friendly causes, such as the purchase of tracts of forest land in northern Maine to preserve them from development. ${ }^{189}$ 
Spiritual or religious influences were evident in other American start-ups also. In the case of Aveda, it was Indian spirituality. This company was the creation of Horst Rechelbacher, whose father had been a shoemaker and his mother an herbalist in Austria in the Nazi period. Poverty led to an early end to his schooling and apprenticeship as a hair dresser. Aged 17 in 1958, he moved to Rome and London to work in salons, and five years later to New York. He opened his own salon in Minneapolis in 1965, after being hit by a drunk driver whilst attending a hair show, which left him hospitalized for six months and owing huge medical bills. Rechelbacher built a successful salon business, but the task left him exhausted.

Rechelbacher became interested in Eastern meditation. After hearing the Swami Rama, then a prominent Indian guru, speak at the University of Minnesota, Rechelbacher followed him to India in 1970 and stayed for six months, where he studied the use of herbs and plants to promote health and longevity. When he returned to the United States he began developing products for his salons using the essential oils derived from plants, introducing American consumers to ayurvedic philosophy and aromatherapy. In 1977 he established a cosmetology school. Aveda Corporation - a name inspired by Rechelbacher’s India experience - was founded in 1978 in Minneapolis. The first product, a clove shampoo, was formulated in his kitchen sink. The first products were all hair care products initially manufactured to be used exclusively at Rechelbacher's chain of hair salons in Minnesota. Over the following years he popularized the concept of aromatherapy, which linked the sense of smell to health and well-being, and developed a technology to produce "natural" permanent waves and botanically-augmented clay masks for the skin. The product range was steadily expanded from hair care to a full range of beauty products. ${ }^{190}$ 
Religion remained less evident among the entrepreneurs in Europe, but the association between greenness and strong business ethics was very much present. These sentiments were evident in l'Occitane, founded by a 23 year old literature student Olivier Baussan in 1976. This was based in the southern French region of Provence making shampoos, colognes and bath essences and founded on the principle of pure products and principled business ethics. Using second-hand soap machinery acquired in 1980, the small company also began manufacturing soap, beginning a transformation in the image of Marseilles soap. In 1980 the first l'Occitane shop or boutique was opened in Volx. However this was destined to remain a small business for many years. ${ }^{191}$

\subsection{Niche to Mainstream}

During the 1970s growing health concerns about the chemical ingredients used in many cosmetics created a more favorable context for natural cosmetics. These concerns were heightened by weak or non-existent regulation. American manufacturers of beauty products still did not voluntarily label ingredients, despite the passage of the 1966 Fair Packaging \& Labeling Act by which cosmetic product ingredient labeling was, in theory, mandated. ${ }^{192}$ Mandatory labeling of cosmetic products was instituted in the United States in 1973, although important exceptions to the law remained, including products for professional salon use only and product samples as well as the option firms had to apply for exceptions, citing protection of trade secrets. Fragrance ingredients were exempted altogether from this labeling legislation. ${ }^{193}$ This was an unsatisfactory situation to face the mounting scientific evidence concerning the potentially carcinogenic ingredients used in hair dyes. ${ }^{194}$ This research caused a temporary crisis for the major hair dye brands, which led to product reformulations. Clairol, the market 
leader in the United States, declared on its packaging that the product had been changed. The color of Clairol's modified dyes was lighter, and the slogan "new clear formula same great color" was printed on the bottle label. ${ }^{195}$

In Europe, there were similar concerns and a resulting explosion of consumer-related laws during the 1970s. In Germany, the Law on Food and Cosmetics in 1975 imposed standards on safety and labeling, and regulated additives and advertising, though the beauty industry was left to self-regulate its conformity to these standards. In France, the Law on Cosmetic and Hygiene Products in 1975 required new products to be approved by the Ministry of Health, and information about new products distributed to anti-poison centers throughout the country. ${ }^{196}$

This provided an incentive, and more favorable context, for a new set of entrepreneurs entered the industry with a more commercial and more ambitious vision. In 1976 Anita Roddick established a store selling skin and hair care products in Brighton, on the south coast of England. Roddick, the daughter of Italian immigrants, had been involved previously in women's rights issues in developing countries while working for an international agency in Geneva, and had later traveled throughout Africa and the South Pacific. The decision to open a beauty shop when she was aged 34 was made after she and her husband Gordon sold their small hotel business to finance his wish to spend two years riding on horseback from Buenos Aires to New York City. ${ }^{197}$

Roddick's vision was straightforward. She wanted to sell cosmetics in different sizes, rather than big bottles, and she wanted to use cheap containers, feeling that many women felt, as she did, "conned" that much of the cost of cosmetics was due to "fancy packaging". She was also determined to use natural ingredients, an idea inspired by seeing the traditional beauty practices of women in Tahiti and elsewhere during her travels. "It was a revelation to realize", she later 66 
wrote, "that there were women all over the world caring for their bodies perfectly well without ever buying a single cosmetic”. After approaching cosmetics manufacturers, including the leading British pharmacy retailers Boots, to make products for her, and being told that the ingredients she proposed were "ridiculous", she employed ingredients made from a radical young local herbalist and frustrated make-up artist, Mark Constantine, later to found Lush in the 1990s. Roddick prepared product batches in her own kitchen, and packaged them in the cheapest containers she could find - urine-sample bottles. ${ }^{198}$

The first store - named The Body Shop - worked well, and when her husband returned in 1977 after his horse died crossing the Andes, the couple pursued a new strategy of franchising their business. Roddick's conviction that business practices needed to be guided by "feminine principles" of love and intuition, and the emphasis on cheap packaging, natural and environmentally friendly ingredients, proved a powerful marketing success, as did her explicit denunciation of the industry for exploiting women by making false claims. The first international franchise, a kiosk in Brussels opened in 1978, shops were opened in Stockholm and Athens in the following year, and by 1982 two new stores were being opened every month. All the early franchisees were women. By 1984, the year before it went public, The Body Shop, had sales of almost $\$ 7$ million, with 45 outlets in Britain and 83 in other countries. ${ }^{199}$ The Body Shop’s success lay in turning natural cosmetics, previously the preserve of niche and frequently affluent consumers, into a mass market business.

Like John Mackey, Roddick strove to combine profitability with social mission. In 1996, The Body Shop began sponsoring posters for Greenpeace, which was then lobbying against the dumping of hazardous waste in the North Sea. This led on to a sustained involvement 
with Greenpeace and later Friends of the Earth. Roddick aimed to combine responsibilities to staff, consumers and the environment with its returns to shareholders. Roddick strove to achieve a wholly holistic approach to greenness. The company used soy inks to print catalogs on recycled paper, and promised it would plant two trees for every tree used to make the paper for its catalogues. Every employee was required to take part in a community service project for at least one hour a week, on company time. ${ }^{200}$ In 1992, Body Shop published its first environmental statement called "The Green Book”.

The Body Shop was not the only natural beauty firm which suddenly found itself attractive enough to access the external capital markets. Robertet went public with a listing on the Paris Stock Exchange's Secondary Market, reflecting the new value that markets placed on a firm that had chosen to remain devoted to natural ingredients. The company was able to use its new funds to expand its American business by buying a US company. ${ }^{201}$

In 1990 Estée Lauder, the large US cosmetics company which focused on prestige department stores, sanctified the natural category by establishing Origins Natural Resources Inc. This was the first mainstream beauty company to take the natural category seriously. Twenty years previously the firm had created the Clinique brand with its famous white-coated sales people emphasizing the medicinal and scientific features of the brand. It now entered the green world with a brand which used recycled paper and makeup shades which emphasized natural skin tones, while avoiding animal products and petroleum-based active ingredients. Origins was offered via freestanding boutiques in Cambridge, Mass, and SoHo, New York City, which became the basis for a growing retail business. Greenness was again associated with public philanthropy, with the company donating a proportion of sales to local good causes. In 1997 Estée Lauder also paid \$300 million to buy Aveda. 
The leading US cosmetics trade journal identified the impact of the "bandwagon" in “exploiting a growing consumer awareness of the environment” in 1991:

"This awareness is being sharpened by a kaleidoscope of media stories relating to chemical degradation of the earth's atmosphere, destruction of the rain forests and wetlands, pollution of the sea and some major rivers, acid rain, deteriorating air quality over major population centers, and discovery of plastic wastes and heavy metals in remote quarters of the globe. Each story or tv program tends to reinforce, make more palatable or desirable, the message and the offerings of the Body Shops, Avedas, and Origins." ${ }^{202}$

There was no sudden rush to follow Estée Lauder from the mainstream industry, but there were an increasing number of new entrepreneurial entrants into the sector, including many with a strong commitment to organic principles. These included the founders of Jurlique, now the premier Australian natural skin care brand. Dr. Jurgen Klein and his wife Ulrike, both trained in Germany as biochemists, emigrated to Australia in 1983 along with their four children. Klein, who was also qualified as a naturopath, had been fascinated by "studying ancient and modern knowledge of natural remedies and therapies, both Eastern and Western... from the age of fourteen.” He applied that knowledge to building Jurlique, which the couple founded in 1985, after discovering near Adelaide "the cleanest, most unpolluted environment to grow herbs and flowers." Klein met initial skepticism but, as he later described, "by anticipating customer desires, we developed a product line that provides a pathway to improving health and wellbeing." ${ }^{203}$ A substantial business developed with the plant and herbal ingredients sourced from biodynamic farms in South Australia.

In France there was a strong distinction between natural and organic (or "bio" as it was known) cosmetics. A key figure was the Swiss-born Rodolphe Balz, who had graduated in 69 
sociology and geography, and then taught it before deciding to move to France to become a farmer. Balz was interested in the therapeutic values of plants and essential oils, and was heavily influenced by his mother, who had grown medicinal and aromatic plants in her yard, and had known prominent naturopaths. ${ }^{204}$ Balz joined Nature et Progrès, and helped draft the first standards for organic agriculture. In 1986 he launched Sanoflore Laboratory, which specialized at first in the organic production of aromatic and medicinal plants, and organic shampoos, shower gels and massage oils. Eight years later Balz launched his first organic cosmetics, though he found few takers, as few consumers knew what the term meant. ${ }^{205}$

The lack of definitions was a familiar issue but one which caused serious problems for natural cosmetics. While standards and certification for organic foods had finally been put in place by the 1990s, attempts to create regulations for beauty products continued into the new century. In 1995 Balz tried to get the makers of organic cosmetics to agree on standards, but found little enthusiasm. ${ }^{206}$ Most products labeled "natural" still contained some synthetic fragrances, artificial dyes or petroleum by-products. This reflected a basic scientific issue that usually only a small element of a plant that has, for example, skin benefits. Extracting this component from the plant requires a process that is synthetically derived. Plant-based preservatives also have poor antimicrobial and antifungal properties, so preservatives are essential to keep moulds and bacteria from growing in products containing water, which can in turn give rise to serious skin complications. ${ }^{207}$

\section{Inventing Green washing}

As the natural market segment became attractive, it attracted firms which belonged to the mainstream of their industries. This raised the possibility of "green washing". In its purest form, 
this has been defined as "the intersection of two firm behaviors: poor environmental performance and positive communication about environmental performance."208 However as the beauty industry in particular shows, uncertainty and disagreement about what constituted "natural" or sustainable products, demands a broader definition of "green washing." The emergence of a profitable natural consumer market encouraged many firms which were not necessarily engaged in damaging the environment to exploit consumer uncertainty about the meaning of sustainability by portraying themselves as "green."

During the 1970s the potential value of the term "natural" began to attract the attention of leading companies in the beauty industry, especially those based in Europe. During that decade Unilever began selling its Sunsilk shampoo, a mass shampoo brand originally launched in 1954, in affluent European markets as providing "natural beauty", although in developing countries it was social aspirations rather than "nature" which was stressed. ${ }^{209}$ The company took this natural positioning one stage further when it took a deodorant from its Finnish business called Timotei, and launched it as shampoo in Sweden in 1976. The product's formulation was based on a wide grass called Timothy grass (hence the name), and the shampoo was packed in a white bottle with green text and cap and a small oval green/white flower and grass design. It became a highly successful shampoo brand marketed in multiple countries as "naturally mild", and advertised by a succession of often blonde female models standing in fields. ${ }^{210}$

The major beauty companies had, in fact, never ceased using "natural" ingredients in their products, because it was known that plant extracts contained actives that affected skin, hair and performed other cosmetic functions. ${ }^{211}$ As companies responded to the natural wave of sentiment, they typically added plant extracts to the same base formulas used in their existing 
products, not least because the use of pure natural products greatly raised the cost and complexity of cosmetics, because of the problems of preservation. This encouraged a general feeling in the mainstream beauty industry that the "natural" movement was a naïve niche fad. This belief was re-inforced by consumer confusion about what natural beauty care really meant, and the lack of regulation which specified the percentage of natural ingredients in a formula necessary to make the claim of being natural. ${ }^{212}$

This sentiment was strong at L’Oréal, the French-owned company which was amongst the five biggest beauty companies in the world. L’Oréal's initial response to the "natural” trend was to emphasize instead innovation and development of its pharmacy brands. In 1978, however, as the demand for natural products showed no signs of abating, it slowly adopted a more positive stance. Already, in its annual report in 1978, the firm announced that it had responded to consumers who desired plant-based products, but only with "extremely serious products which we are not content merely to promote by making an allusion to Nature.” The brand that became the first designated plant-brand was Kerastase, its upscale hair brand, with two new plant-extract based products launched in 1978, but for much of the 1980s the brand strategy can be described as trying to balance an image around both natural and scientific concepts without privileging either dimension. $^{213}$

Big business was also aware of the growing consumer interest in being "natural” in the United States. As in Europe, there was a growing concern for the environment, and for things regarded as "natural”, such as all-natural fibers and denim blue jeans in fashion. After the hexachlorophene in Cover Girl was banned, Clairol launched a Clean Makeup campaign which emphasized outdoor scenes and natural look. ${ }^{214}$ By the 1970 s mainstream companies were 
engaged in search for organic and natural ingredients which avoided allergic reactions. There was the appearance of milk and honey in moisturizers, and the growing use of herbs. Retail sales of hypo-allergenic beauty products were estimated to have reached $\$ 50$ million in $1971 .{ }^{215}$ Shampoos made from balsams, herbs, and lemons, and skin creams made from avocados all made their appearances. ${ }^{216}$ In 1973 Elizabeth Arden opened a new hair salon on the tenth floor of its building on the Fifth Avenue, New York, which was designed as botanical environment with hanging plants, with crab apple trees and seasonal plants at the entrance. ${ }^{217}$ During the late 1970s Clairol captured a large share of the American shampoo market with Herbal Essences, a green shampoo with a high fragrance content based on the essences of sixteen herbs and wildflowers. ${ }^{218}$

In general, though, American consumers and mainstream companies were less interested in European-style "natural" cosmetics. The use of botanicals was primarily a European phenomenon throughout the 1970s and most of the 1980s, reaching fashionable New York stores from imports from European companies. ${ }^{219}$ This may have reflected in part the lack of equivalent of a pharmacy channel which was important for natural cosmetics products in some European countries. There were also differences in consumer preferences. American consumers remained especially interested in the transformational effect of make-up, and welcomed ingredients that appeared to work, whilst Europeans had stronger preferences for skin care. In all markets, there were conflicts in consumer minds between wanting to be green and seeking performance, a tension which was not helped by the higher prices of natural products, as ingredients were typically more costly to purchase and process than synthetic ones. ${ }^{220}$

Meanwhile disagreements as to what constituted natural or green not only hindered the development of the category, but caused disagreements within it. When Balz, for example, 73 
encountered Roddick and the Body Shop, he was not impressed by the quality of their products, from his perspective. He later observed:

"The Body Shop was a good idea originally... but honestly, I have to tell you, they produce nothing but low quality. Their products, if you only looked into their composition, were not of the best quality. But they were marketing geniuses, and the woman, the owner was really nice and approachable, she had great ideas, and a lot of ethics, but her ethics were focused more on people than the composition of her products. She didn't know much about natural really and even less about bio. One day they came to me and asked me to provide them with 5 tons of bio (organic) lavender essential oil...I told them, do you realize that it’s approximately the country's yearly production of bio lavender oil right? That speaks volumes about their knowledge in the field." 221

Nor was Balz the only critic of The Body Shop. As the company grew, it attracted critics. In 1994 Business Ethics, a bimonthly magazine with a circulation of 14,000, published an article called "Shattered Image" which alleged that some of the Body Shop's products contained cheap, petrochemical laden ingredients, that lax quality-control permitted the sale of contaminated products, and that charitable giving was actually small. When the Body Shop received news of the article, it first threatened to sue the magazine, and when it was published, obtained the subscriber list without authorization and sent out a ten-page refutation to the magazine' s readers signed by Gordon Roddick, then the company chairman, asserting that the article was "filled with lies, distortions, and gross inaccuracies."222

In foods, too, as firms became bigger, and mainstream retailers asserted their "greenness", issues of legitimacy and green washing rose to the fore. The pioneers of natural 
foods, such as Paul Keene of Walnut Acres, saw the irony of the situation, but also needed to take a judgment on the issue of legitimacy. Keene summarized his own feelings in 1988.

“The large multinational food companies, having first unmercifully ridiculed the truth-seekers' eccentricity, began ever so cautiously to reverse themselves...Unable to hold back the wave of the future, they decided to ride it in. we are reminded of three phases of growth of a new idea. First, people reject it; second, they ridicule it; third, they claim it as their own. ..Because we were one of the early and best-known groups in the field at that time, we were approached by several of these large corporations. They wondered if we would be interested in supplying them with natural foods. We did not care either to be compromised or to be swallowed up, and se we did not parley with them long. Nevertheless, good has come out of their approach, and the world is better for their change in direction. Walnut Acres could not feed the whole planet, and half a loaf is better than one.,223

There was a paradox that the very success of the pioneering entrepreneurs in creating green as a market segment resulted in the entry of many, larger firms whose green credentials and commitment were questionable. The phenomenon was widespread among business cultures where "green" emerged as profitable. In Germany, for example, critics either used the English word or the German "'Gruenfaerberei", meaning coloring it green. Meanwhile the growth of larger firms such Whole Foods aroused growing accusations not necessarily of green washing, but of the dangers of "corporate organic."224 Certainly scale had consequences. The pioneers of organic foods and agriculture had sold their products as part of a broad social and environmental vision. This vision was often presented to purchasers in shops and other outlets, either formally 
or informally. In a large Whole Foods store, or a mainstream supermarket selling organic foods, consumers could purchase the product without receiving the wider vision.

Certification and the institutionalization of organic agriculture also raised issues of legitimacy. A highly critical study of organic agriculture in California by Guthman observed how, in the specific context of that U.S. state, organic farming increasingly took the same form as agribusiness. The structure of the organic sector emerged to look a lot like the structure of agriculture as a whole. A small number of farms dominated the market. In 19972 percent of Californian growers grossed more than 50 percent of the total value of organic production. Some talked of an "organic-industrial complex," and noted an incoherence in philosophy and approach which raised doubts about whether organic was making a real contribution to a more sustainable world. $^{225}$

\section{Asia, Africa and Latin America}

The emergence of natural food and beauty has been told so far in terms of Western countries of North America and Western Europe. By 2010 these two regions accounted for 90 per cent of the world market for organic food and drink. ${ }^{226}$

The slow growth of the Japanese market for green consumer products was odd. Traditional Japanese culture and spirituality had always put a high regard on harmony with nature. Moreover, in the post-1945 era, individual Japanese, including Fukuoka in organic farming, and Ohsawa and the Kushi's in the macrobiotic movement, had been major influences on Western thought. However there were also powerful counter influences, including postwar Japan's desire for modernization and fast growth, and its collective disregard for many past traditions. There was a traditional Japanese word for organic called "yuki" which meant organic 
compound. It was used to describe organic farming because chemical fertilizers were inorganic/mineral whereas fertilizers used in traditional farming were organic. The "yuki" concept became particularly associated, even more than the organic movement elsewhere, with radical and left-wing movements. This included opponents of the plans to build Tokyo's new airport at Narita during the 1960s and 1970s, who undertook organic farming in the surrounding area as they blocked construction. The upshot was that when a new generation of entrepreneurs started to create organic businesses during the 1980s and 1990s, they felt obliged to seek their inspiration from Europe, especially Germany and France, rather than past Japanese traditions. ${ }^{227}$

Elsewhere, in many developing countries, the slow pace of modernization meant that they entered the twentieth century less exposed to the widespread application of chemistry to agriculture and consumer products. In some cases lack of development facilitated a jump straight into the burgeoning Western organics market from the 1970s. In the coffee industry, for example, while the major producing countries of Brazil and Colombia "industrialized" their production systems during the postwar decades, the much less developed Mexican industry did not, enabling it to successfully enter the US coffee organic market towards the end of the century.

As the century progressed, environmental concerns were often sacrificed for growth. This produced, on occasion, remarkable responses. In Colombia, for example, by the interwar years millions of acres of rainforest and tropical dry forest to create fields were cleared for sugar cane and cattle, releasing as a result carbon into the atmosphere, causing droughts and erosion, eliminating wildlife habitat and degrading rivers. The family-owned El Hatico farm in Cauca Valley in the southwest of the country took another route. During the interwar years the owner, Ciro Molina Carés, who was also a secretary of agriculture in the region, refused offers of sugar 77 
companies to install plants. He articulated strong sustainability concerns, arguing that "deforestation in the region was one of the main causes of imbalances.” This provided the basis for a family tradition which has continued until the present day. As all the neighboring farms were converted to sugar cane, El Hatico has persisted until the present day with mixed-use farming on organic principles with no use of chemical inputs. ${ }^{228}$

A subsequent pioneer of organic farming was Ibrahim Abouleish in Egypt. Born in Egypt, he studied chemistry and pharmacology in Austria, and stayed at the University of Graz as a researcher during the 1970s. In 1975, on a visit to Egypt, he was shocked by the environmental degradation and poverty in the country. He had read the work of Rudolf Steiner, and in 1977 he returned to the country and purchased 70 acres of desert land in Belbes, 60 kilometers northeast of Cairo and four kilometers from the Suez Canal from the state, and established Sekem, taking its name from the hieroglyphic transcription meaning "vitality of the sun”, to develop biodynamic farming methods. As for many other green entrepreneurs, there was a strong religious motivation behind Abouleish's actions - in this case Islam. ${ }^{229}$ He later explained the relationship between his views derived from Steiner and Islam:

“Anthroposophy has no link with religion..it is just a philosophy, but it does help you understand the world you live in. Religion brings ethics and morals. I cannot function without the one or the other.. both religion and anthroposophy are important to me. I need to add that my religion Islam needs more entrepreneurs, entrepreneurs that are able to explain religion in a modern way so they are not considered as greedy people, but as a factor of development, a sustainable development."230

It was no easy matter to start organic farming in a desert. He and a local villager began reclaiming land and beginning to make it cultivable. This was a long-term project which 
involved planting some 120,000 trees. In order to finance such a project, Abouleish sought foreign markets. He employed his knowledge of pharmacology to start making medicinal products, at first for the international market. In 1981 Sekem sent its first shipment of medicinal herbs and food ingredients to the United States. Two years later it began selling herbal remedies on the local market. This developed into a business which packed organically certified herbal teas, dairy products, oils, spices, honey, dates, organic coffee, juices and conserves for consumers in Egypt and abroad.

In 1986 Abouleish worked with the German Development Bank and a German natural medical products company called Dr. Schaete to create ATOS PHARMA, a joint venture to research and develop medicines from natural sources. Six years later ATOS began manufacturing and selling natural cosmetics under license from the German company Weleda. In Egypt, Sekem began selling its organic food during the early 1980s. There were no organic foods in the market at all, so Abouleish needed to create awareness through slowly building contacts with journalists.

Abouleish sought to progressively widen the scope of the crops he grew organically. In 1988 he and a Greek partner set up another company called Libra to produce and sell locally and internationally organically grown crops. He drove the creation of an industry association, notably the Egyptian Biodynamic Association, which pioneered the growing of biodynamic cotton from 1991. Sekem also extended its own agricultural business. In 1994 Libra began to grow 1000 acres of cotton biodynamically, based on intensive cooperation between scientists, manufacturers, and farmers. Trained and experienced advisors helped small-scale farmers, weekly visiting different regions to answer questions and solve urgent problems such as insect development. In 1996 a disagreement between Abouleish and his partners on what constituted organic led him to withdraw from Libra, and found a new company called Hator to produce and pack fresh fruit and vegetables. ${ }^{231}$

Abouleish also developed a wider educational role. This began with the so-called “Chamomile children” in 1984, a response to child labor in Egypt. The children, aged between ten and fourteen years, were for the most part from the disadvantaged rural areas around the 
SEKEM community, and had their own teachers who looked after them for the whole day. In addition to schooling, the children worked picking herbs at Sekem and received a cooked meal everyday. The program also included medical care when needed. After attending the school they received a report, like the other children, confirming that they were now literate. They were also given a chance to learn a skill at the vocational school at Sekem. The girls working for SEKEM were also taught about nutritious and healthy eating, knitting and embroidery. In 1987, Abouleish opened the Mahad, a center for adult education, in a building especially designed by a German architect who was a friend of Abouleish, and designed to give an institutional framework to educate adults. The Mahad also provided education for children with handicaps.

Subsequently, Sekem launched a kindergarden and this provided the foundation for a new wave of pedagogical work beginning in 1988. Both Europeans and Egyptians trained in Germany were hired as kindergarten teachers. In the following year Sekem established its first schools opened to people living outside the community with first and seventh grade classes. This grew over the following decades into an extensive school open to students of all religions, extending from kindergarten to higher education, and aimed at "trying to teach our youth from a very young age the importance of respecting the environment they live in.”232

Indigenous traditions sometimes provided a basis for entrepreneurs to enter into modern green industries. In Colombia, for example, Labfarve laboratories was founded in 1971 by Jorge Piñeros Corpas, a prominent Colombian doctor and scientist, who initially sought to make more affordable medicines using plants and traditional practices, sourcing ingredients from the peoples of the Amazon. The company diversified in time to cosmetics. ${ }^{233}$

In neighboring Brazil, Natura, a direct selling company founded by Antonio Luiz da Cunha Seabra in 1969, became increasingly concerned with the use of sustainable methods and 80 
ingredients during the 1980s, again sourcing them from the Amazon. Natura, which became the country's largest beauty company, formed part of a cluster of companies were both successful and shared strong green values. These included O Boticário, founded in 1977, which shared Natura's strong commitment to high ethical standards and the environment, establishing in 1990 a non-profit organization to preserve the natural environment. ${ }^{234}$

The cases of the Brazilian beauty companies illustrate the association of greenness with social justice which became apparent in many emerging markets from the 1980s. In organics, as Asian and then Latin America societies joined in the late 1980s and early 1990s, IFOAM's agenda shifted to reflect concerns of the South, especially social justice. In 1992 IFOAM was represented at the FAO’s Rio Conference. In 1992 in the Sao Paul declaration titled “Organic Agriculture, a key to a sound development and a sustainable environment”, the federation established a new model that linked social justice with environmental protection. ${ }^{235}$

\section{Conclusions}

By 2000 the natural food and beauty categories remained small, as measured by the overall size of the world market, and as measured by the size of these categories by 2012 . Nonetheless the foundations for subsequent growth had been laid. This had been achieved by a lengthy process of new category creation involving the exercise of entrepreneurial imagination. The pioneering entrepreneurs reviewed in this working paper faced little consumer demand for natural products, and little consumer knowledge of what they entailed. They imagined a world different from their own, and proceeded to execute their vision.

The creation of these new categories involved three overlapping waves of entrepreneurship. First, as the careers of Abouleish, Aubert, Balfour, Geoffroy, Rodale and many 
others showed, the diffusion of ideas through publishing, and promotion of research and education, engaged many entrepreneurs. They were, in effect, making the ideological case for natural products, and providing the basis for them to be made available. Second, entrepreneurs engaged in the creation of industry associations which could advocate, as well as give the nascent industry credibility and create standards. Finally, entrepreneurial ventures established retail stores, supply and distribution networks, and created brands.

The process of new category creation was difficult. It was challenging to build reliable supply networks, and to build distribution facilities. It was difficult to explain the benefits of natural products to consumers, and to convince them to pay (often) a premium. It was especially hard to convince consumers because there were multiple and evolving definitions what "natural" meant, a problem re-inforced by conflicting or no formal standards. In the broadest terms, greenness emerges as a social construct whose definition was diffuse and constantly changing. The association between green and social entrepreneurship, which became especially strong in some businesses originating in the South towards the end of the twentieth century, was one illustration of the changing definitions of what it meant to be green.

The empirical evidence assembled here does not provide the basis to provide a systematic analysis of the kind of people engaged in such endeavors. This paper has focused on influential, not representative, figures. No attempt has been made to capture the entire population of entrepreneurs in natural food and cosmetics. It is evident, however, that many of the pioneers identified here are illustrative of the category which Walley and Taylor, in one pioneering attempt to construct a typology of green entrepreneurs, have described as "visionary champion" and "ethical maverick." They were figures who intended to build a green business from the beginning. ${ }^{236}$ Although they differed in their ultimate visions, they shared a belief that the nature 
of the opportunity they were pursuing was more about the transformation of the world rather their personal bank accounts. Not surprisingly, such people were regularly dismissed as eccentric and foolish. Only as natural became an established segment did established firms move into green business.

Entrepreneurial cognition and motivation frequently lay in individual, and very local, experiences. It was striking how many individual entrepreneurs suffered from personal illnesses which appeared to have motivated their subsequent careers. The many examples included Lust, Hawken, Siegel, Rodale, Geffroy, and Fukuoka. The early development of businesses in local, remote or unfashionable locations was the norm. This was evidently the case of pioneering organic farmers such as Balfour, Ford, Rodale, let alone Fukuoka, who lived in rural isolation for decades, but it was also true more generally. Yves Rocher wanted to save a village in rural Brittany. Organic retailing in the United States began with a small below-street level store in Boston. Roddick's Body Shop originated in a small store in Brighton on the south coast of England.

In contrast to such individual and local origins, many of the key pioneers in these industries were highly globalized in their world views, with strong perception of how their own small, local efforts related to much bigger and global pictures. A significant number of the early figures, including Hans Müller, Frank Ford, Tom Chappel and Eve Balfour, related their efforts to Christian visions of the world. This motivation continued with later entrepreneurs such as Thomas Harrtung. Mo Siegel was motivated by a world view that he found in the Urantia book. Rudolf Steiner's concepts of biodynamic agriculture were rooted in the esoteric-occult world view of anthroposophy which was heavily influenced by Eastern religions. Abouleish was a devout Muslim. This evidence should not be interpreted as supporting a general hypothesis that 83 
religious people were more likely than non-religious people to become natural food or beauty entrepreneurs. Rather, the evidence presented here is suggestive that a significant sub-set of the influential historical figures reviewed here were articulate in expressing strong religious convictions.

The early green entrepreneurs travelled extensively and/or lived for significant periods of time in other parts of the world, especially Asia, where they were introduced to agricultural, healing, and exercise practices, ideas and belief systems, and cultural and religious traditions which motivated or strongly influenced the development of their green business activities. In both food and cosmetics, exposure to India or Japan was a significant influence on several pioneering entrepreneurs. Indian spirituality was important in the thinking of Benedict Lust and Horst Rechelbacher, as well as John Mackey. The macrobiotic movement was driven by ideas from Japanese spirituality. While not every green entrepreneur subscribed to a strong belief system or followed a movement associated with one, many did, inventing products and founding firms they hoped would contribute to their overall vision.

It was striking that the small and marginal local businesses which pioneered green business were so heavily influenced by global flows and exchanges of ideas. There was a notable international transfer of ideas and concepts. The roots of organic farming in Britain lay India through the work of Howard and McCarrison. The nineteenth century health reform movements in the United States and Britain exchanged ideas. Lust and Pfeiffer personally transferred concepts developed in Germany into the United States. Geffroy transferred German Reform House concepts to France. Michio and Aveline Kushi moved to the United States from Japan. Hawken went to live and study in Japan in the early days of Erewon, and then moved on to a 
New Age community in the north of Scotland. Roddick was inspired for the ideas about the Body Shop by seeing women in Tahiti. Abouleish was exposed to the ideas of Steiner in Austria.

There was also an early recognition that solutions to environmental issues needed to be international and not local. This recognition had already been seen with the international societies to protect birds and nature, and promote vegetarianism, before World War 1. After World War 2, this recognition had led to the creation of globalized advocacy groups, such as the Soil Association and, later, the Friends of the Earth. The formation of international associations such as IFOAM was an early recognition that if the organic market was to become firmly established, it needed to be defined convincingly so that consumers could trust and understand products, and in an age when people travelled, this definition could not vary hugely between countries without undermining confidence. The achievement of such standards proved a challenging mission.

Already by the 1990s it was evident that the success of entrepreneurial pioneers in building a legitimate category of green products carried a new set of issues. It encouraged a much wider range of businesses to enter natural categories, some genuinely, but others seeking to green wash conventional businesses. This created confusion and skepticism in consumer minds. There were also legitimacy issues caused by growing scale. As organic agriculture went mainstream, some talked of an "organic-industrial complex." Both Anita Roddick and John Mackey were indicative of a new generation of entrepreneurs who sought to combine their ideals, which were not confined to the environment, with rapid business growth, profitability, and flotation on the capital markets. Whilst they and others saw no contradiction, others would come to be suspicious and critical of such "industrial organic." 


\section{Endnotes}

${ }^{1}$ Loubna Bouamane conducted many of the interviews in this paper, and her research has contributed greatly to it. I would also like to thank Oona Ceder, Dick Hollander, Chris Marquis, Ellen Mølgaard, Simon Mowatt, Eric Stam, Bart van Hoof, and Mayuka Yamazaki for their advice and assistance, as well as participants of seminars at Auckland University of Technology, New Zealand, the National Graduate Institute for Policy Studies in Tokyo, Japan and Utrecht University in the Netherlands for helpful comments. I am grateful to the Auckland University of Technology, Copenhagen Business School, and Universidad de los Andes in Bogota for inviting me as a visitor and enabling some of the research which went into this paper. This research project was funded by the Division of Research and Faculty Development at the Harvard Business School.

${ }^{2}$ See also Geoffrey Jones and Loubna Bouamane, "Historical Trajectories and Corporate Competences in Wind Energy," Harvard Business School Working Paper, No. 11-112, May 2011 and Idem, "'Power from Sunshine': A Business History of Solar Energy," Harvard Business School Working Paper, No. 12-105, May 2012.

${ }^{3}$ Helga Willer and Lukas Kilcher, The World of Organic Agriculture. Statistics and Emerging Trends 2011 (FiBL-IFOAM Report. IFOAM, Bonn and FiBL, Frick, 2011); Organic News, “Global growth in the natural cosmetics sector”, January 192011.

${ }^{4}$ Swiss Important Promotion Programme, The Organic Market in Europe, accessed on May 29 2012 at www.sippo.ch/.../food.../SIPPO_Manual_18.04.2011_final.pdf 
${ }^{5}$ G. Berle, The Green Entrepreneur: Business Opportunities that Can Save the Earth and Make You Money (Blue Ridge Summit, PA: Liberty Hall Press, 1991). J. Blue, Ecopreneuring: Managing For Results (London: Scott Foresman, 1990); J. Elkington, and T. Burke, The Green Capitalists (London: Victor Gollancz, 1989); R. Isaak (1998) Green Logic: Ecopreneurship, Theory and Ethics (Sheffield: Green Leaf Publishing, 1998); Michael Schaper (ed.), Making Ecopreneurs: Developing Sustainable Entrepreneurship (Aldershot: Ashgate, 2005).

6 Stephen Hussey and Paul Thompson, "Introduction: The Roots of Environmental Consciousness”, in Stephen Hussey and Paul Thompson (eds.), Environmental Consciousness (New Brunswick: Transaction Publishers, 2004), pp.1-18. Anna Bramwell, Ecology in the $20^{\text {th }}$ Century. A History (New Haven: Yale University Press, 1989) remains a valuable survey of the emergence and growth of environmental concerns, even if some of the arguments (for example, on the green policies of the Nazi’s) need to be supplemented by more recent research.

7 “The Evolution of the Conservation Movement, 1850-1920," memory.loc.gov/ammem/amrvhtml/conshome.html, accessed August 22011.

8 Christine M. Rosen, “Businessmen Against pollution in late Nineteenth Century Chicago,” Business History Review, 69 (Autumn 1995), pp. 351-367.

${ }^{9}$ Russell J. Dalton, The Green Rainbow. Environmental Groups in Western Europe (New Haven: Yale, 1994), pp. 25-33.

10 “The Evolution.” 
${ }^{11}$ John Foster and Fred Magdoff, “Liebig, Marx, and the depletion of soil fertility: Relevance for today's agriculture,” Monthly Review: An Independent Socialist Magazine, 3, Jul/Aug98, 50, pp. $32-45$.

12 Dalton, Green, p. 33.

${ }^{13}$ Gesine Gerhard, “Breeding Pigs and People for the Third Reich,” in Franz-Josef Brüggemeier, Mark Cioc and Thomas Zeller (eds.), How Green were the Nazis? (Athens: Ohio University Press, 2005).

${ }^{14}$ Dalton, Green, pp.34-35; www.worldwildlife.or, accessed August 12011.

15 “Minamata Disease: The History and Measures,” The Ministry of the Environment (2002), accessed at http://www.env.go.jp/en/chemi/hs/minamata2002/; “Minamata Disease Archives,” the National Institute for Minamata Disease, accessed at http://www.nimd.go.jp/archives/english/index.html August 2 2011; Masazumi Harada, Minamata Disease (Kumamoto Nichinichi Shinbun Centre \& Information Center/Iwanami Shoten Publishers, 1972); S. Timothy George, Minamata: Pollution and the Struggle for Democracy in Postwar Japan (Cambridge, Mass: Harvard University Press, 2001); Jun Ui, Industrial Pollution in Japan (United Nations University Press, 1992), Chapter 4, section IV; W. E. Smith and A. M. Smith, Minamata (London: Chatto \& Windus, Ltd., 1975).

${ }^{16}$ Geoffrey Jones, Renewing Unilever (Oxford: Oxford University Press, 2005), pp. 342-3.

${ }^{17}$ Jones, Renewing, p. 340. 
${ }^{18}$ Gunnar Trumbull, Consumer Capitalism. Politics, Product Markets, and Firm Strategy in France and Germany (Ithaca: Cornell University Press, 2006), pp.72-90.

${ }^{19}$ Oskar Broberg, "Labeling the Good: Alternative Visions and Organic Branding in Sweden in the Late Twentieth Century,” Enterprise \& Society, 11, 4, (2010) p. 817.

${ }^{20}$ In 1972 DDT was banned in the United States.

${ }^{21}$ Jean Dorst, Avant que nature meure (Neuchatel: Neuchatel Delachaux et Niestlé, 1965); Paul Ehrlich, The Population Bomb (New York: Ballatine Books, 1968)

22 "In the middle of the $20^{\text {th }}$ century, we saw our planet from space for the first time." (Our Common Future: World Commission on Environment and Development (Oxford and New York: Oxford University Press, 1987), p. 3.

${ }^{23}$ Marc Lampe and Gregory M. Gazdam, “Green Marketing in Europe and the United States: an Evolving Business and Society Interface”, International Business Review, 4, 3 (1995), p.302.

${ }^{24}$ William E. Siri, "Reflections on the Sierra Club, the Environment and Mountaineering, 1950s1970s,” An Interview Conducted by Ann Lage Co-chairman, Sierra Club History Committee, Regional Oral History Office The Bancroft Library, UC Berkeley, CA. April 1979.

${ }^{25}$ http://www.clubofrome.org/eng/about/3/, accessed on April 7, 2010.

${ }^{26}$ Donella H. Meadows, Dennis L. Meadows, Jørgen Randers, and William W. Behrens III, The Limits to Growth: a report for the Club of Rome's project on the predicament of mankind (New York: Universe Books, 1972).

${ }^{27}$ Dalton, Green, pp.38-39. 
${ }^{28}$ Manuel Rodriguez-Becerra and Bart van Hoof, Environmental Performance of the Colombian Oil Palm Industry (Bogota: Fedepalma, 2005), p. 20.

${ }^{29}$ Roland de Miller, “Un Seule Terre: Stockholm 1972”, Nature et Progrès, Newsletter n4, October, November, December 1972. pp. 20-29.

${ }^{30}$ www.squidoo.com/earth-day-and-Shaklee, accessed August 112011.

31 This act required every federal agency in the United States to prepare an Environmental Impact Statement for any legislation. In 1970 the Environmental Protection Agency was created.

32 Russell J. Dalton, “The Environmental Movement in Western Europe,” in Sheldon Kamieniecki (ed.) Environmental politics in the international arena: movements, parties, organizations, and policy (Albany: SUNY Press, 1993), pp. 52-3.

${ }^{33}$ United Nations, "Process of preparation of the Environmental Perspective to the Year 2000 and Beyond,” General Assembly Resolution 38/161, 19 December 1983.

${ }^{34}$ Our Common Future: World Commission on Environment and Development (Oxford and New York: Oxford University Press, 1987), p. 43.

${ }^{35}$ Sylvester Graham, two-volume Lectures on the Science of Human Life (1839).

${ }^{36}$ Frank Murray and Jon Tarr, More than One Slingshot: how the health food industry is changing America (Richmond, VA: Marlborough House 1984), pp. 13-14; Samuel Fromartz, Organic, Inc. (New York: Harcourt, 2006), pp.153-5.

${ }^{37}$ Derek Oddy, From Plain Fare to Fusion Food (London: Boydell, 2003), chapter 3 
${ }^{38}$ Colin Spencer: The Heretic's Feast. A History of Vegetarianism (London: Fourth Estate 1993), p. 252-253, 261-262.

${ }^{39}$ Murray and Tarr, More, p. 13.

${ }^{40}$ Spencer, Heretic's Feast.

${ }^{41}$ Ray Hill, The health food store: A nostalgic look at the first - its origins, philosophy and development (Nuhelth Books: Stroud, 1998), pp.5-10.

${ }^{42}$ Murray and Tarr, More, chapter 1.

43 This association was renamed the National Health Foods Association, and in 1970 became the National Nutritional Foods Association. This remains the health food industry's trade association.

${ }^{44}$ Hill, The health food store, pp.14-15.

${ }^{45}$ Conford, Origins, explores the German influence on the early U.S. natural food and organic movement.

${ }^{46}$ Gordon Kennedy, Children of the sun: a pictorial anthology, from Germany to California 1883-1949 (Ojai, Calif.: Nivaria Press, 1998), pp. 54-61; Gordon Kennedy and Kody Ryan, “Hippie Roots \& The Perennial Subculture,” available at http://www.hippy.com/php/article243.html, accessed on August 20, 2009.

47 Florentine Fritzen, Gesünder leben: Die Lebensreformbewegung im 20. Jahrhundert (Franz Steiner Verlag: Stuttgart, 2006). 
48 Arlette Harrouch, “Le rôle de Nature et Progres dans l'histoire de la bio en France: Témoignage d’une actrice engagée”, Nature et Progrès newsletter, issue 44, NovemberDecember 2003.

${ }^{49}$ Kennedy and Ryan, “Hippie Roots”.

${ }^{50}$ Kennedy, Children, pp. 125-126.

${ }^{51}$ Kennedy and Ryan, “Hippie Roots”.

${ }^{52}$ Kennedy, Children, pp. 125-26.

${ }^{53}$ Kennedy and Ryan, "Hippie Roots"; Benedict Lust, Yungborn: The Life and Times of Dr. Benedict Lust and Pilgrimages to the Great Masters (Healing Mountain Publishing, reprinted 2006); and Friedhelm Kirchfield and Wade Boyle, Nature Doctors (NCMN, 1994).

${ }^{54}$ Kennedy and Ryan, “Hippie Roots”; Lust, Yungborn; and Boyle, et al, Nature Doctors.

55 Ben Yagoda, “The True Story of Bernard Macfadden. Life and Loves of the Father of Confession magazine”, www.americanheritage.com/articles/.../ah/.../1981_1_22.shtml. Accessed August 22011.

${ }^{56}$ Robert L. Shook, The Shaklee Story (New York: Barnes and Noble, 1982), chapter 1.

${ }^{57}$ Ibid, pp. 97-100.

58 Holger Kirchmann, Gudni Thorvaldsson, Lars Bergström, Martin Gerzabek, Olof Andrén, Lars-Olov Eriksson, and Mikael Winninge (eds.) “Fundamentals of Organic Agriculture” in H. Kirchmann and L. Bergström (eds) ,Organic Crop Production - Ambitions and Limitations, 
(Dordrecht: Springer. 2008), pp.13-38; G. Vogt, “The Origins of Organic Farming”, in William Lockeretz (ed.), Organic Farming:An International History (Trowbridge: Cromwell Press, 2007), pp.14-16.

${ }^{59}$ G. Vogt, Entstehung und Entwicklung des ökologischen Landbaus im deutschsprachigen Raum (Bad Durkheim: Stiftung Oekologie und Landbau, 2000) provides a history of the German organic movement.

${ }^{60}$ Vogt, “Origins, pp. 19-22. Conford, Origins, pp.67-70.

${ }^{61}$ Northbourne, Looking to the Land, p. 58; John Paull, “The Surprising History and Geography of the first 'organic farming' Association”, Agri-Food XV, University of Sydney, 26-28 November 2008, http;//orgprints.org/15097.

${ }^{62}$ http://www.pfeiffercenter.org/about_us/ehrenfried_pfeiffer.aspx, accessed July 272011.

${ }^{63}$ Arie Hollander, ““Tegen Beter Weten In’. De Geschiedenis van d Biologische Landbouw en Voeding in Nederland (1880-2001), Utrecht University Phd, 2012. I am grateful to Dick Hollander for sharing his work with me.

${ }^{64}$ Hollander, “'Tegen’.”

65 John Paull, "From France to the World: The International Federation of Organic Agriculture Movements (IFOAM), Journal of Social Research \& Policy, 2 (December 2010), p.94.

${ }^{66}$ Oxford Dictionary of National Biography, "Sir Albert Howard” (on-line version). Albert Howard, An Agricultural Testament (London and New York: Oxford University Press, 1940) This was a continuation of an earlier book, The waste products of agriculture, published in 1931. 93 
See also Warren J. Belasco, Appetite for Change (Ithaca: Cornell University Press, 1993); Michael Pollan, The Omnivore's Dilemma: A Natural History of Four Meals (New York: Penguin Press, 2006); and Samuel Fromartz, Organic, Inc. (New York: Harcourt, 2006).

${ }^{67}$ Howard, Agricultural Testament.

${ }^{68}$ Conford, Origins, pp. 62-71-2.

${ }^{69}$ Vogt, “Origins”, p.25.

${ }^{70}$ Eve B Balfour, The Living Soil (London: Soil Association, 2006 edition).

${ }^{71}$ P. Conford and P. Holden, "The Soil Association”, in Lockeretz (ed.), Organic Farming, p.192; Carsten Daugbjerg and Darren Halpen, "Governing growth in organic farming. The evolving capacities of organic groups in the United Kingdom and Denmark,” Paper for the $58^{\text {th }}$ PSA Annual Conference, 1-3 April 2008, accessed at http:orgprints.org/13951.

72 William Lockeretz, Organic farming: an international history; http://www.biolelivre.com/Hans-Peter-Rusch-1906-1977.html, accessed on July 222011.

${ }^{73}$ Hollander, “'Tegen’.”

74 “Association les Guides de la Nature de la Vie et de la Santé, "Biographie d'Henri-Charles Geffroy précurseur en écologie: Pourquoi "L'Alimentation Saine"?” http://agnvswebmestre.free.fr/biographie_nadh.html, accessed August 42011.

${ }^{75}$ Arlette Harrouch, "Le rôle de Nature et Progres dans l'histoire de la bio en France: Témoignage d'une actrice engagée”, Nature et Progrès newsletter, issue 44, November- 
December 2003; Jean- Mari Morin, “ L’agriculture biologique : « de la naissance aux évolutions actuelles”, Conference Proceedings Chambre régionale d'agriculture des Pays de la Loire à destination des enseignants agricoles, November 112010.

${ }^{76}$ Interview with Richard Marietta, June 8 2011, Paris.

${ }^{77}$ Paul Keene, "Fear not to Sow" because of the Birds (Chester, Conn: Globe Pequot, 1988), p.vii.

${ }^{78}$ Packaged Facts, The Organic Food and Beverage Market 1996 ", Pub ID LA-41900 (April 1996); George deVault, “What Became of Walnut Acres,” The Natural Farmer (Spring 2006).

${ }^{79}$ Daniel Gross, Our Roots Grow Deep. The Story of Rodale (Reading, Penn: Rodale Inc, 2008), pp.1-44.

${ }^{80}$ Gross, Our Roots, p. 48.

${ }^{81}$ Gross, Our Roots, pp. 55-63.

${ }^{82}$ Packaged Facts, Organic Food and Beverage Market.

${ }^{83}$ Gross, Our Roots, pp. 70-74.

${ }^{84}$ Gross, Our Roots, pp. 96-100, 106.

${ }^{85}$ Warren J. Belasco, Appetite for Change (Ithaca: Cornell University Press, 1993), p. 71.

${ }^{86}$ Gross, Our Roots, pp.110-117, 114-132. 
${ }^{87}$ http://casfs.ucsc.edu/about/history/farm-garden-projects, retrieved on September 27 2011; Julie Guthman, Agrarian Dreams: The Paradox of Organic Farming in California (Berkeley: University of California Press, 2004), p. 16.

${ }^{88}$ Interview with Myra Goodman, March 152012.

89 www.onestrawrevolution.net, accessed August 4 2011; “Japanese Farmer-Philosopher Masanobu Fukuoka: Natural Farming Greening the Deserts" Japan for Sustainability, Newsletter May 2006, http://www.japanfs.org/en/mailmagazine/newsletter/pages/027813.html, accessed August 42011.

${ }^{90}$ Gross, Our Roots, pp.137-9.

91 Interview by Ellen Farmer with Jim Cochran, December 10 2007, UC Santa Cruz Library, Oral History Collection, "Cultivating a Movement: An Oral History of Organic Farming and Sustainable Agriculture on California’s Central Coast.”

92 Interview with Myra Goodman, March 152012.

93 Rodale Institute, “The History of Community Supported Agriculture, Part I Community Farms in the 21st Century: Poised for Another Wave of Growth?" accessed at newfarm.rodaleinstitute.org/features/0104/csa-history/part1.shtml, June 22012.

${ }^{94}$ Michael Ableman and Alice Waters, On Good Land: The Autobiography of an Urban Farm (San Francisco: Chronicle Books,1998)

${ }^{95}$ Shook, Shaklee Story, pp. 45.

${ }^{96}$ Fritzen, Gesünder, pp.112-5. 
97 Susanne Padel and Uli Zerger, “ Economics of Organic Farming in Germany,” in N.H. Lampkin and S. Padel (eds.), The Economics of Organic Farming (Wallingford: CAB International, 1994), p. 91.

98 John Bloom, “Doing what comes naturally.... Made Frank Ford healthy and wealthy,” Texas Monthly, June 1979, p. 86.

${ }^{99}$ Ibid, p. 82.

${ }^{100}$ Ibid.

101 http://www.arrowheadmills.com/about-us/history.php, accessed on September 2, 2009. Arrowhead Mills was acquired by The Hain Celestial Group in 1999. Hain purchased Celestial Seasonings in 2000 .

102 John Bloom, “Doing,” p. 86.

${ }^{103}$ Ibid, p. 82.

${ }^{104}$ Ibid, p. 84.

${ }^{105}$ Ibid, pp. 82-84.

${ }^{106}$ Hawken’s most influential works include Paul Hawken, Amory Lovins and L Hunter Novins, Natural Capitalism (Boston: Little Brown, 1999).

${ }^{107}$ History of Erewhon- Natural Foods Pioneer in the United States (1966-2011), 
www.soyinfocenter.com/pdf/Erewhon.pdf, accessed July 30 2011. The reconstructed Erewon acquired U.S. Mills, a cereal company founded in 1906, in 2006, taking the latter as the corporate name.

${ }^{108}$ Paul Hawken, The Magic of Findhorn (New York: Harper \& Row, 1975). Findhorn remains in existence - www.findhorn.org.

109 Mo Siegel, “Colorado Country Boy Finds A Revelation,” in Jack Canfield and Gay Hendricks, You've GOT to Read This Book!: 55 People Tell the Story of the Book That Changed Their Life (New York: Harper Collins, 2006).

${ }^{110}$ Siegel, “Colorado Country Boy;” Joyzelle Davis, “High tea with Mo Siegel - Former Celestial boss talks about Whole Foods, his investment firm, improving lives,” Rocky Mountain News, November 3, 2007, accessed on September 42009 at http://m.rockymountainnews.com/news/2007/nov/03/high-tea-with-mo-siegel/

${ }^{111}$ Davis, “High tea”.

${ }^{112}$ Siegel, “Colorado Country Boy.”

${ }^{113}$ Ibid.

${ }^{114}$ Mike Taylor, “The natural wonder of Boulder: 'we're going to revolutionize the way people eat', ColoradoBiz, March, 2005, accessed on September 152009 at http://findarticles.com/p/articles/mi_hb6416/is_3_32/ai_n29164723/

115 http://www.celestialseasonings.com/about/timeline.html, accessed on June 2, 2010; and Taylor, "Natural wonder.” 
${ }^{116}$ http://www.celestialseasonings.com/about/timeline.html, accessed August 22011.

117 Ibid

118 See Company History, www.wholefoodsmarket.com, accessed April 28 2012. In 1996, Wild Oats became a public company traded on NASDAQ. Wild Oats was acquired by Whole Foods Market in 2007.

119 “The Hain Celestial Group, ”Historywww.hain-celestial.eu/about_history_en.php, accessed January 122012.

120 "Commercialisation au Salon de la Diététique", 3 Nature et Progrès Newsletter, n4 4 , October, November, December 1966, p. 23.

${ }^{121}$ Interview with Claude Aubert, January 122012.

122 Ibid.

123 Alexandra Pohl, “Organic Farming in Austria”, accessed at http;//www.organic-europe.net, February 122012.

${ }^{124}$ Interview with Janet and Grant Brians, July 19 2007, in UC Santa Cruz Library, “Cultivating a Movement.”

${ }^{125}$ History of the CCOF, http://www.ccof.org/images/logo.gif, accessed February 132012.

${ }^{126}$ Christopher Marquis, Marya Besharov, Bobbi Thomason and Leah Kaplow, "Whole Foods:

Balancing Social Mission and Growth,” Harvard Business School Case, 9-410-023 (August 29 2009). 
127 P. Conford and P. Holden, “The Soil Association”, in Lockeretz (ed.), Organic Farming, p.192.

128 Denis Bourgeois, "How it all began," International Federation of Organic Agriculture Movements (2005), accessed www.ifoam.org/about_ifoam/inside.../How_IFOAM_Began.pdf, January 82012.

129 “Le Congrès de Versailles, 3, 4, 5 Novembre 1972” Nature et Progrès Newsletter n4, Ninth year, October, November, December 1972.

${ }^{130}$ B. Geier, "IFOAM and the History of the International Organic Movement” in Lockeretz (ed.), Organic Farming: An International History (Trowbridge: Cromwell Press, 2007), pp. 175185.

${ }^{131}$ B. Geier, “IFOAM.”

132 Saki Ichihara Fomsgaard, "The Evolution and Status of Organic Principles in an International Perspective.”

${ }^{133}$ Darren Halpin, Carsten Daugbjerg and Yonatan Schvertzman, “Interest-group capacities and infant industry development: State-sponsored growth in organic farming,” International Political Science Review (June 2011), p.153.

${ }^{134}$ Interview with Richard Marietta, June 8 2011, Paris.

135 Stephan Dabbert, Anna Maria Häring, Raffaete Zanoli, Organic Farming: Policies and Prospects (New York: ZEB Books, 2003); Arlette Harrouch, "Le rôle de Nature et Progres dans l’histoire de la bio en France: Témoignage d'une actrice engagée”, Nature et Progrès newsletter, 100 
issue 44, November-December 2003; Jean-Mari Morin, "L'agriculture biologique : « de la naissance aux évolutions actuelles”, Conference Proceedings Chambre régionale d'agriculture des Pays de la Loire à destination des enseignants agricoles, November 11 2010; Schmid, “Development of Standards for Organic Farming,” in Lockeretz, Organic, pp.152-156.

${ }^{136}$ Marquis et al, "Whole Foods.”

${ }^{137}$ Ibid.

${ }^{138}$ Wendy Zellner, “Whole Foods: Moving Tofu into the Mainstream,” Business Week, May 25 1992.

${ }^{139}$ Fromartz, Organic Inc, p.155.

${ }^{140}$ William B. Tate, “The Development of the Organic Industry and Market: An International Perspective,” in Lampkin and Padel (eds.), Economics, pp. 22-23.

${ }^{141}$ Laurence Weinstein and Cindi Bigelow (of the R.C. Bigelow Tea Company), "The R.C. Bigelow Tea Company Case Study,” The CASE Journal, vol. 2, Issue 1 (Fall 2005), p. 40, available at http://caseweb.org/journal_sub/TheCASEJournalVolume2Issue1.pdf\#page=28, accessed on June 16, 2010.

142 Joyzelle Davis, "High tea with Mo Siegel - Former Celestial boss talks about Whole Foods, his investment firm, improving lives,” Rocky Mountain News, November 3, 2007, accessed on September 42009 at http://m.rockymountainnews.com/news/2007/nov/03/high-tea-with-mosiegel. 
143 http://www.celestialseasonings.com/about/timeline.html and Taylor, “Natural wonder,” accessed August 22011.

144 Davis, "High tea."

${ }^{145}$ http://www.celestialseasonings.com/about/timeline.html, accessed August 22011.

146 Ibid.

${ }^{147}$ Ibid and Davis, “High tea.”

${ }^{148}$ http://www.celestialseasonings.com/about/timeline.html, accessed August 22011.

149 “A Widening popularity brings Acquisitions,” New York Times, October 261996.

150 United States Department of Agriculture, "Report and Recommendations on Organic Farming", prepared by the USDA Team on Organic Farming, July 1980.

151 Ibid

152 FAO, World Markets for Organic Fruit and Vegetables - Opportunities for Developing Countries in the Production and Export of Organic Horticultural Products (2001), accessed at http://www.fao.org.ezp-prod1.hul.harvard.edu/DOCREP/004/Y1669E/y1669e00.htm, April 30 2012.

${ }^{153}$ FAO, World Markets.

154 Ibid.

155 Hollander, “'Tegen’.”

${ }^{156}$ FAO, World Markets. 
${ }^{157}$ SIPP, Organic Market in Europe, p.97.

${ }^{158}$ Interview with Karsten Korting and Thomas Roland of the FDP, May 222012.

${ }^{159}$ SIPP, Organic Market in Europe, p. 97.

${ }^{160}$ Interview with Karsten Korting and Thomas Roland.

${ }^{161}$ FAO, World Markets.

${ }^{162}$ Interview with Thomas Harrtung, May 222012.

${ }^{163}$ Interview with Thomas Harrtung. Aasrstiderne has sales of \$45 million in 2012.

${ }^{164}$ Hollander, “'Tegen'.”

165 Paulin Köpfer and Helga Willer, “Organic Viticulture in Germany”, Paper prepared for BIOBACCHUS, International Organic Wine Conference, Frascati, Villa Aldobrandini, 5-6 May 2001

${ }^{166}$ Interview with Eric Hartl, January $27^{\text {th }} 2012$.

167 Ibid.

${ }^{168}$ Uwe Hofmann and Stiftung Ökologie \& Landbau; compiled by Eva Gehr, Stiftung Ökologie \& Landbau, April 2001.

${ }^{169}$ Interview with Patrick Frick, November $19^{\text {th }} 2011$.

${ }^{170}$ Don Lotter, “Portrait of a pioneering California organic wine family”, September 28 2004, The New Farm, accessed at www.newfarm.org, August 142012.

${ }^{171}$ Interview with Jonathan Frey, October 112011. 
172 Lotter, "Portrait.”

173 Helga Willer and Raffaele Zanolt, “Organic Viticulture in Europe”, http//:www.orgprints.org/1917.

${ }^{174}$ W. Blake Gray, “Why isn't more wine 'organic'?” Los Angeles Times, January 62011.

175 Tataina Bouzdine-chameeva and Anna Krzywoszynskam, "Barriers and driving forces in organic winemaking in Europe: case studies in France and Italy,”, 6 ${ }^{\text {th }}$ AWBR International Conference, Bordeaux Management School, 9-10 June 2011, accessed at academyofwinebusiness.com/?page_id=565, June 22012.

${ }^{176}$ Geoffrey Jones, Beauty Imagined (Oxford: Oxford University Press, 2010), chapter 1.

177 See Yvonne Barbara Houy, “'Of Course the German Woman should be Modern’: The Modernization of Women’s Appearance during National Socialism” (unpublished Cornell University PhD, 2002).

${ }^{178}$ http://cosmeticsandskin.com/bcb/lash-lure.php, accessed July 272011.

${ }^{179}$ http://www.fda.gov/centennial/centennial_files/textonly/slide17.html accessed April 8, 2009; Norman F. Estrin (ed.) The Cosmetic Industry: Scientific and Regulatory Foundations (New York: Marcel Dekker, 1984), pp. 164-169.

180 http://www.drbronner.com/history_overview.html accessed April 82009.

${ }^{181}$ L’Oréal Archives, Paris (hereafter L’Oréal); L’Oréal 1970 Annual Report; Frost \& Sullivan, Cosmetics \& Toiletries Markets in Europe (New York: Frost \& Sullivan Inc., January 1985), p. 357. 
182 “Color Surge in Italy Drives Nail Care Sales”, Drug and Cosmetic Industry (May 1998)

183 Jacques Courtin, Une Réussite en beauté (Paris: JC Lattès, 2006), Adam Bernstein “Jacques Courtin-Clarins: founded skin care firm”, Boston Globe April 2 2007; “Clarins gets personal with new brand”, WWD, 3 August 2007; Pete Born, “Clarins’ Vision Quest”, WWD Beauty Biz, vol. 195, 130 (June 20 2008).

${ }^{184}$ www.robertet.com, accessed August 82011.

185 www.drhauschka.com/about-dr-hauschka, accessed August 22011.

186 Arne Hoegberg, Skoenhetens Entreprenoer: Knut Wulff beraettar om sitt liv (Malmoe: Corona Foerlag, 2004), p.109.

187 Björn Edsta, Jonas \& Robert of Oriflame (Stockholm: Ekerlids, 2008), pp. 46-7; Interview with Robert af Jochnick, April 202007.

188 Tom Chappell, The Soul of a Business (New York: Bantam, 1994)

189 www.burtsbees.com, accessed May 22009.

${ }^{190}$ http://www.fundinguniverse.com/company-histories/Aveda-Corporation-CompanyHistory.html, accessed June 21, 2008; http://www.rakemag.com/reporting/features/horst-rakishinterview, accessed June 21, 2008.

191 Pierre Magnan, The Essence of Provence. The Story of L'Occitane (New York: Arcade Publishing, 2003), pp. 60-87.

${ }^{192}$ Estrin, Cosmetic, pp. 164-169. 
193 Frost \& Sullivan, Inc., The Cosmetics and Toiletries Industry Market, (New York: August, 1972), p. 47; Peter Barton Hutt, “A History of Government Regulation of Adulteration and Misbranding of Cosmetics,” in Norman F. Estrin and James M. Akerson, Cosmetic regulation in a competitive environment (New York: Informa Health Care, 2000), p. 22; http://www.personalcarecouncil.org/Content/NavigationMenu/About_Us/History/History.htm accessed March 252009.

${ }^{194}$ Estrin, Cosmetic, pp. 168-171.

195 “As Hair Dyes Change, Confusion and Complaints Abound,” New York Times, April 23, 1979; 50 Colorful Years. The Clairol Story (the company, 1982), p. 45.

196 In Germany 313 new consumer laws were passed between 1970 and 1978, compared to 25 in the previous 25 years. In France, the number of consumer laws rose from 37 in 1970 to 94 in 1978. See Trumbull, Consumer, pp.8-9, 89-96.

197 Anita Roddick, Body and Soul: Profits with Principles- The Amazing Success Story of Anita Roddick \& the Body Shop (New York: Crown Publishers, 1991), p. 67.

198 Roddick, Body, p. 69-73.

199 Christopher A. Bartlett, Kenton W. Elderkin and Krista McQuade, The Body Shop International, Harvard Business School Case no. 9-392-032, (July 13, 1995).

200 “Environmentally Friendly: The Bandwagon Gathers Speed!”, DCI (December 1991, pp3133).

${ }^{201}$ www.robertet.com

202 “Environmentally Friendly,” pp.31-2. 
203 “Dr. Jurgen Klein, Founder of Jurlique International”, Healing Lifestyles and Spars, accessed at https://www.healinglifestyles.com/index.php/healing-profile-jurgen-klein, February 122012. Jurlique was sold to the Japanese beauty company Pola for \$300 million in 2011.

${ }^{204}$ For Balz's views on the therapeutic value of plants and essential oils, see Rodolphe Balz, The Healing Power of Essential Oils (Twin Lakes, WI: Lotus Light, 1996).

${ }^{205}$ Interview with Rodolph Balz, April 13th 2011.

${ }^{206}$ Ibid.

${ }^{207}$ Ogle, "Beauty."

${ }^{208}$ Magali A. Delmas and Vanessa Cuerel Burbano, "The Drivers of Greenwashing," California Management Review, 54, 1 (2011), p. 65.

209 Jones, Renewing, pp. 165-6.

${ }^{210}$ Ibid, p. 122.

${ }^{211}$ Tala Aburjal and Feda M. Natsheh, "Plants used in Cosmetics", Phytotherapy Research, 17 (2003), pp.987-1000.

${ }^{212}$ Frost \& Sullivan, The Hygiene and Grooming Aids Market (January 1974), p. 45 V 8.

${ }^{213}$ Jones, Beauty.

${ }^{214}$ Linda Scott, Fresh Lipstick (New York: Palgrave Macmillan, 2005), pp, 274-5.

${ }^{215}$ Frost \& Sullivan, Hygiene, pp.38 V 1-45 V 8. 
${ }^{216}$ Frost and Sullivan, Cosmetics, pp. 70.

217 “A New Angle on Naturalness’, Cosmetic World, October 291973.

21850 Colorful Years. The Clairol Story (the company, 1982), p.4.1. Dyer, et al Rising Tide ,p.

111.

219 Jane Ogle, “Beauty: Beneficent Botanicals”, New York Times, February 221981.

${ }^{220}$ Euromonitor International, The Growth of Natural Ingredients (July 2005)

${ }^{221}$ Ibid.

${ }^{222}$ Maureen Clark, “Socially Responsible Business Brawl: Business Ethics' Magazine Criticizes Cosmetic Maker Body Shop, The Progressive, March 1995, accessed at findarticles.com/p/articles/mi_m1295/is_n3_v59/ai_16839646, accessed August 22010.

${ }^{223}$ Keene, Fear, p. 61.

${ }^{224}$ Marquis, "Whole Foods.”

${ }^{225}$ Guthman, Agrarian Dreams, chapter 3.

${ }^{226}$ GMID, Certified Organic; Recession No Serious Threat to Organic Food and Drinks (Part 1), December 2011.

${ }^{227}$ Interview with Yasushi Tamura at Mavie Akasaku store, Tokyo, May 242010. 
${ }^{228}$ Interview with Enrique Jose Molina, Bogota, March 14 2010; Tracy L. Barnett, "El Hatico cattle ranch: The problem is the solution,” The Esperanza Project. A Green News Portal for the Americas, accessed January 122012.

${ }^{229}$ Ibrahim and Helmy Abouleish, "Garden in the Desert: Sekem makes comprehensive sustainable development a reality in Egypt," Innovations: Technology, Governance, Globalization , 3 (3) (2008), p. 94.

${ }^{230}$ Interview with Ibrahim Abouliesh, October 52011.

${ }^{231}$ Abouleish, “Garden, ” p.103.

${ }^{232}$ Interview with Ibrahim Abouliesh; Ibrahim Abouleish, SEKEM: A Sustainable Community in the Egyptian Desert (Edinburgh: Floris Books, 2005), pp. 167-70.

${ }^{233}$ Interview with Gustavo Urrea, Bogota, March 142010.

${ }^{234}$ Geoffrey Jones and Ricardo Reisen de Pinho, "Natura: Global Beauty Made in Brazil”, Harvard Business School Case, No. 9807 029; Geoffrey Jones, "The Growth Opportunity That Lies Next Door," Harvard Business Review 90, nos. 7-8 (July - August 2012).

${ }^{235}$ Fomsgaard, "Evolution and Status.”

${ }^{236}$ Isaak, Green Logic; Liz Walley and David W. Taylor, "Opportunists, Mavericks..?A Typology of Green Entrepreneurs,” in Schaper (ed.) Making. 